\title{
SECURED CREDIT AND BANKRUPTCY: A CALL FOR THE FEDERALIZATION OF PERSONAL PROPERTY SECURITY LAW
}

\author{
David M. Phillips*
}

\section{INTRODUCTION}

We frequently assume that a state of affairs as we find or experience itwhether that state of affairs be cultural, institutional, or personal-both is, and should be, the norm. This "objectivization" arguably functions to facilitate acceptance of our environment, but it also makes critical assessment difficult and change often beyond contemplation. To what degree does this egocentric phenomenon operate in law, and more specifically among legal scholars? It might be thought to operate little, for legal scholars seem constantly to be engaged in an inquiry into what the law should be. But even those who participate in that inquiry frequently start with fundamental assumptions about the status of law that go unchallenged as other policy issues are confronted. And if the assumption relates to the supposed form of the law, as opposed to its content, there seems to be a lesser tendency to recognize and correct anomaly. The stranger to our legal system does not share this perceptual problem, as he has not yet adapted to this legal environment in which we write and teach.

One such anomaly that the stranger to our universe of American commercial law would immediately recognize-but that we seem not to recognize or at least acknowledge publicly any more-is the continued existence of and interplay between two separate bodies of law that integrally relate to each other: the Bankruptcy Code, ${ }^{1}$ as the present embodiment of federal bankruptcy law, and article 9 of the Uniform Commercial Code, ${ }^{2}$ as the present embodiment of personal property security law. That interplay assumes a particularly curious mode because of the differing authority to be

\footnotetext{
Copyright $\odot 1987$ by Law and Contemporary Problems

* Professor of Law, Northeastern University. I would especially like to thank Professors Vern Countryman, Douglas G. Baird, Ira Lupu, and Melvin G. Shimm, as well as various faculty members at Northeastern University Law School for comments on an earlier draft of this article. I would also like to thank Ms. Susan Robinson of the Boston University Law School, class of 1986, and Messrs. David Bunker and Claude d'Estree of Northeastern University Law School, classes of 1986 and 1988, respectively, for their research help.

1. 11 U.S.C. \$ 101-1328 (Supp. III 1979) [hereinafter cited as the "Bankruptcy Code"].

2. The Uniform Commercial Code is sometimes hereinafter referred to as the "UCC." Unless the context otherwise requires, references to the Code are to the 1978 edition.
} 
accorded to each body of law-one as federal statutory law and the other as state statutory law.

In itself, the Uniform Commercial Code is a heroic attempt, not always successful, to secure the sameness of law for commercial transactions throughout the United States through the process of having over fifty legislatures independently enact the same legislation. This effort to produce sameness through attempted state uniformity has historical roots in late nineteenth-century and early twentieth-century constitutional interpretation that the federal government's power did not extend to commercial transactions that, viewed in isolation, took place wholly within a single state. ${ }^{3}$ But though this constitutional interpretation was repudiated half a century ago, we still accept as normal a concomitant legislative posture that confronts basic policy issues relating to personal property security interests and their validity only awkwardly and with difficulty.

Hence, this article argues that the law of personal property security interests should be federalized and integrated with the Bankruptcy Code. The first part of the article tells why a federal approach to sameness of personal property security law makes more sense than a uniform state approach. The second part discusses the advantages of integrating that body of law with the Bankruptcy Code.

\section{II}

\section{A Federal Versus a Uniform State Approach}

Before we explore those considerations that are currently material to preferring either a federal or a uniform state approach to personal property security law, it will be useful to elucidate two historical background factors. The first is that while the suggestion to federalize this aspect of commercial law is novel, the importance of federalizing certain other aspects of commercial law has been recognized and, indeed, federalization has been attempted. ${ }^{4}$ The second is the state of constitutional jurisprudence at the end of the nineteenth century and beginning of the twentieth century, which cast commercial law as more appropriately the subject of uniform state rather than federal legislation.

The most prominent of past federalization attempts, of course, was the 1842 opinion of Justice Story in Swift v. Tyson. ${ }^{5}$ Justice Story signally succeeded. For almost a hundred years thereafter, the rule of this case, as the common law, was applied by federal courts to commercial disputes, even when suit was brought on diversity grounds. ${ }^{6}$ About fifty years later, in 1890 ,

3. See infra notes $19-26$ and accompanying text.

4. For an exposition of efforts early in our national history, see generally $1,2 \mathrm{~W}$. Crosskey, Politics and the Constitution in the History of the United States (1953).

5. 41 U.S. (16 Pet.) 1 (1842).

6. It is interesting to note that this federalization of much of the law relating to commerce accorded with views expressed even at the beginning of the nineteenth century. For example, James Sullivan, the governor of Massachusetts, wrote in favor of such a development in 1801 . See J. Sullivan, History of Land Titles in Massachusetts 353-54 (1801); 1 W. Crosskey, supra note 4 , 
a bill was introduced in Congress to regulate interstate commerce and to codify the law concerning commercial paper. ${ }^{7}$

Interestingly, one of the most vocal proponents of federalization in twentieth-century America was Professor Karl Llewellyn, at least several years before he became the chief reporter for the Uniform Commercial Code. ${ }^{8}$ Almost fifty years ago, a federal sales act that would apply to interstate and foreign sales transactions was proposed, ${ }^{9}$ and Professor Llewellyn emerged as one of its most vigorous drumbeaters. ${ }^{10} \mathrm{He}$ supported this legislation not only to achieve uniformity, but also, in truth, "to clarify the major ambiguities in the application of the Uniform Sales Act to more recent conditions" 11 and "to correct any important errors of theory or of practical measure which are shown by thirty-four years of experience to have crept into the Uniform Sales Act."12 In short, one of Professor Llewellyn's first legislative attempts to correct the perceived shortcomings of the Uniform Sales Act was actively to support other legislation that de facto would govern an increasing number of sales transactions. His quite transparent motive to undermine the Uniform Sales Act, ${ }^{13}$ however, may have spelled the death of the proposed federal sales act, which was successfully opposed by Professor Samuel Williston, the Uniform Sales Act's author, and his Harvard allies. ${ }^{14}$

But the concept of a federal sales act persisted. The drafters of the Uniform Commercial Code, with Professor Llewellyn at the helm, initially proposed federal enactment of the bulk of the UCC. ${ }^{15}$ The principal omission from the proposed federal version-curiously enough-was article 9.16 By this time, moreover-a decade since Professor Llewellyn first had urged adoption of a federal sales act-the Harvard commercial law cadre had come around and itself taken up the federalization proposal for reasons somewhat similar to Professor Llewellyn's own. Thus, Robert Braucher, then a Harvard

at 36-37. I am indebted to Professor Frank Kennedy for finding these references. See Kennedy, Federalism and the Uniform Commercial Code, 29 Bus. LAw. 1225, 1226 n.2 (1974).

7. H.R. 6957, 51 st Cong., lst Sess., 21 Cong. Rec. 1374 (1890). See Braucher, Federal Enactment of the Uniform Commercial Code, 16 LAw \& ConTEmP. Probs. 100, 101 (1951), for a brief discussion of this bill and similar thinking about federalization during the 1890 's.

8. Professor Llewellyn became chief reporter in 1944. For brief histories of both the UCC and the origins of Professor Llewellyn's participation in the project, which originated as a proposal to revise the Uniform Sales Act, see Schnader, A Short History of the Preparation and Enactment of the Uniform Commercial Code, 22 U. Miami L. Rev. 1 (1967); J. White \& R. Summers, Uniform Commercial Code $1-6$ (2d ed. 1980).

9. H.R. 8176, 76th Cong., 3d Sess. (1940). For a discussion of the proposed federal statute by various scholars, see $A$ Symposium: The Proposed Federal Sales Act, 26 VA. L. REv. 537 (1940).

10. See Llewellyn, The Needed Federal Sales Act, 26 VA. L. REv. 558 (1940).

11. Id. at 562 .

12. Id.

13. See Wiseman, The Limits of Vision: Karl Llewellyn and the Merchant Rules, 100 HARV. L. REV. 465, 479-83 (1987).

14. See, A Statement by Professor Williston, 26 VA. L. Rev. 637 (1940); McCurdy, Uniformity and a Proposed Federal Sales Act, 26 VA. L. Rev. 572 (1940). William E. McCurdy was, like Samuel Williston, a professor at Harvard Law School, and the coauthor, with Professor Williston, of Cases on Sales (1932). Professor McCurdy's 64-page article, supra, amounted to a brief against the federal statute owing, in large part, to its divergence from the Uniform Sales Act.

15. See Braucher, supra note 7 .

16. Id. 
Law School professor, argued in a Law and Contemporary Problems symposium some thirty-five years ago that considerations of uniformity "lead almost inescapably to the conclusion, not that enactment by Congress is desirable, but that enactment without an act of Congress is undesirable."17 Again, however, Congress failed to enact the federal version of the Uniform Commercial Code, although it later adopted the UCC for the District of Columbia. ${ }^{18}$

Despite these various flirtations with federal enactment of commercial law generally, however, no one, to my knowledge, has specifically suggested the federalization of personal property security law. ${ }^{19}$ To the contrary, the pointed omission of article 9 from the proposed federal version of the Uniform Commercial Code demonstrates rather that, like its realty counterpart, personal property security law, even as late in our legal history as the 1950's and early 1960's, was perceived to be within the exclusive province of state law.

Much of this perception-indeed, the most plausible explanation of the current embodiment of most legislative commercial law in uniform state rather than federal legislation-is rooted in constitutional doctrine prevalent in the late nineteenth century and the early twentieth century. Around the turn of the century, it was commonly presupposed that the tenth amendment substantially restricted Congress's ability to regulate commercial activities under the commerce clause. ${ }^{20}$ Drawing the line between federal and state jurisdiction proved a difficult exercise. One bright line, that of United States $v$. E.C. Knight Co., ${ }^{21}$ separating manufacturing or productive processes-deemed to be within the province of state law-from commercial-deemed to be within the province of federal law-lasted no more than ten years before federal encroachment began to be felt. ${ }^{22}$ Federal power was intermittently expanded, but it was not until 1937 that the Supreme Court, in NLRB v. Jones $E^{2}$ Laughlin Steel Corp., ${ }^{23}$ reverted to the broad conception of federal jurisdiction it had articulated in Gibbons v. Ogden. ${ }^{24}$ And since Hodel v. Virginia

17. Id. at 104 .

18. 77 Stat. 630 (1963).

19. Despite the failure of Congress to enact a federal version of the Uniform Commercial Code, calls have intermittently been made for federal enactment. See, e.g., Hintze, Disparate Judicial Construction of the Uniform Commercial Code-The Need for Federal Legislation, 1969 UTAH L. REv. 722 (1969). Most of these calls are ambiguous in terms of whether the proposed federal enactment would mirror the earlier federal version of the UCC that excluded article 9 or would include article 9 as well.

20. See J. Nowak, R. Rotunda \& J. Young, Constitutional Law 150-54 (1983); L. Tribe, american Constitutional Law 232-34 (1978); Corwin, Congress's Power to Prohibit Commerce: A Crucial Constitutional Issue, 18 CORNELL L.Q. 477, 481-84 (1933).

21. 156 U.S. 1 (1895).

22. See, e.g., Swift \& Co. v. United States, 196 U.S. 375 (1905), where the Supreme Court, in an opinion by Mr. Justice Holmes, sustained a Sherman Act injunction against price-fixing by meat dealers on the theory that although the cattle might have been sent for sale within one state, they would soon-and expectedly-enter the "current of commerce" among the states. Id. at 399.

23. 301 U.S. 1 (1937). For another key case laying to rest the vestiges of Knight and its progeny, see Wickard v. Filburn, 317 U.S. 111 (1942).

24. 22 U.S. (9 Wheat.) I (1824). 
Surface Mining E Reclamation Association, ${ }^{25}$ only the political process serves to constrain Congress from regulating even "purely intrastate [commercial activities] ... . where the activity, combined with like conduct by others similarly situated, affects commerce among the States or with foreign nations." "26 The subject matter of Hodel was, of course, the constitutionality of the Surface Mining Control and Reclamation Act of 1977, which, among other things, empowers the Secretary of the Interior to promulgate regulations concerning strip-mining in the various states. ${ }^{27}$

We see, then, that at the time the Uniform Sales Act first was promulgated in 1906, there did, indeed, exist substantial doubt that Congress had the power to enact a general commercial statute applicable to both interstate and intrastate commerce. But today, in contrast, if Congress can constitutionally regulate real estate in the various states (the subject matter of Hodel), few scholars would question the constitutional propriety of federal legislation dealing with personal property-which, by its nature, is less state-specific than is real estate. So, although the history of the interface of the commerce clause with the tenth amendment may explain why the drafters of such antecedents of the Uniform Commercial Code as the Uniform Sales Act and the Negotiable Instruments Law adopted a uniform state rather than a federal approach, the continuation of such an approach is hardly required today. Parenthetically-and without regard to the status of commerce clause jurisprudence-Congress's power to pass bankruptcy legislation ${ }^{28}$ would, in itself, surely support the specific suggestion of this article to federalize personal property security law and integrate it with the Bankruptcy Code. ${ }^{29}$ And whatever the legitimacy of constitutionally-based constraints on Congress's powers under the commerce clause, Professor James Rogers has persuasively argued that constitutionally arguable constraints on Congress's bankruptcy powers lack substantial authority. ${ }^{30}$

Having noted the earlier abortive misstarts at federalizing all or part of commercial law and having disposed of the constitutional issue, we still face the question with which we began: Should personal property security be governed by state law, in the form of uniform legislation, or by federal law? And what criteria should shape our answer?

25. 452 U.S. 264,276 (1981). In fact, since 1937, only once has a federal law or the enforcement of a federal law posited on Congress's commerce clause powers been struck down as an infringement of states' rights under the tenth amendment. See National League of Cities v. Usery, 426 U.S. 833 (1976). But even that case was recently overruled in Garcia v. San Antonio Metropolitan Transit Authority, 469 U.S. 528 (1985). As Professor Gunther remarked, even before the Garcia case, "[a]fter nearly 200 years of government under the Constitution, there are very few judicially enforced checks on the congressional commerce power." G. GunTHER, Constitutional LAW 113 (10th ed. 1980).

26. 425 U.S. at 277.

27. The Act is at 30 U.S.C. $\S \S 1201-1328$ (1979); the regulations provision is $\S 1211$ (c).

28. Art. I, § 8, 4 .

29. Analogously, the restrictions on wage garnishments in the Consumer Credit Protection Act (15 U.S.C. $\$ 1671$ ) are based on the bankruptcy as well as the commerce power.

30. See Rogers, The Impairment of Secured Creditors' Rights in Reorganization: A Study of the Relationship between the Fifth Amendment and the Bankruptcy Clause, 96 HARv. L. REv. 973 (1983). 
The notion of "law" itself suggests one appropriate criterion: the authority that the law carries. The articulation of the question as a choice between uniform state law and federal law implicates a second criterion: the comparative degree of uniformity that could be achieved as between the two. And the current pace of change in commercial markets suggests a third criterion: the ease with which the law could be amended as required. Other factors that should be considered are suggested by the curious history of commercial law already surveyed: federal judicial competence under the regime of Swift $v$. Tyson and state competence, both judicial and legislative, under the various uniform statutes, including the Uniform Commercial Code itself. The principal construct of article 9 , its notice-filing system, suggests that ease of filing and of searching for financing statements should also be considered. Finally, unless much law that extends well beyond the present scope of article 9 were also to be federalized, the ability to separate personal property security law from other aspects of commercial law and from the law of real property mortgages requires comment as well.

\section{A. The Authority of Law}

One would think that a suggestion that commercial law in the United States be federalized would hardly require further advocacy. If a legal framework is necessary or desirable for a particular activity, the legal framework should carry the maximum authority possible.

As Professor Llewellyn stated in support of a federal sales act, federal law offers "a single body of authoritative American law." 31 He added that it was "vital that any Federal Act be set up unmistakably to show itself as the Code of Principle of a Whole Field of Law which it cannot help but be, so that its peculiar character of semi-permanence and analogical development may be made clear in legislative expression."32 This "legal authority" carries a distinct benefit of conducing to a greater certainty of both what the law is and what it may become.

Lack of such legal authority, on the other hand, gives rise to a significant cost flowing from the doctrine of preemption. In our society, federal law and state law, of course, are deemed to be compatible; but where the two legal spheres conflict, directly or indirectly, federal law governs. In the case of article 9 , this preemption has importantly affected both the substantive content of personal property security law and the mode of deciding what that law should be. And although these substantive and decisional effects have perhaps been most celebrated in the context of the interplay between article 9 and the Bankruptcy Code-which will be detailed more extensively laterthey can be observed in other contexts as well.

Consider, for example, the accommodation of security interests and competing federal tax liens. ${ }^{33}$ The substantive law in article 9 that has

31. Llewellyn, supra note 10 , at 558 .

32. Id. at $\mathbf{5 7 0 .}$

33. See 26 U.S.C. $\$ 86321-6323$ (1980), particularly $\$ 6323$ (c) and (d). 
resolved this conflict ${ }^{34}$ may well be defensible, ${ }^{35}$ but it is certainly unclear that its exact contours-the trade-off between future advances of a secured party and tax liens-would have been selected as normatively preferable in the absence of the federal law (tax lien statute)-state law (article 9) conflict. Parenthetically, it should also be noted that the authority accorded law is, to a not inconsiderable extent, a function of its relatively easy accessibility; and although every law student has a copy of the official edition of the Uniform Commercial Code, few have ready access to the nonuniform amendments that have widely proliferated..$^{36}$

Recapitulating then, the federal approach offers a distinct advantage over the uniform state approach to the law governing commercial transactions because under our constitutional scheme, federal law carries greater legal authority and would engender both greater certainty of what the law is and surer control over its development.

\section{B. The Degree of Uniformity}

Nearly every commercial activity in our society affects, even if it does not directly involve, interstate commerce. Rarely are any transactions entirely local in their scope, and there are few who would urge that even strictly intrastate transactions should be governed by law other than that same body of commercial law applicable to interstate and foreign commerce.

We are currently witnessing in a related field-legal regulation of the securities and commodities markets ${ }^{37}$ - the need for law to be coextensive with the activity it purports to govern. These markets are becoming internationalized, as evidenced by recent agreements between Canadian and

34. See UCC \& 9-301 (4) ("A person who becomes a lien creditor while a security interest is perfected takes subject to the security interest only to the extent that it secures advances made before he becomes a lien creditor or within $\mathbf{4 5}$ days thereafter or made without knowledge of the lien. . . ."). The 45-day period during which future advances are protected absolutely against the lien creditor's interest in the collateral is meant to mesh with the provisions of the federal tax lien law. See UCC app.II at $\$ 9-301$, Reasons for 1972 Change (1978). The Tax Lien Act provides that "[e]ven though notice of a lien imposed by section 6321 has been filed, such lien shall not be valid with respect to a security interest which came into existence after tax lien filing by reason of disbursements made before the 46th day after the date of tax lien filing, or (if earlier) before the person making such disbursements had actual notice or knowledge of tax lien filing, but only if such security interest ... is protected under local law against a judgment lien arising, as of the time of tax lien filing, out of an unsecured obligation." 26 U.S.C. $\$ 6323$ (d)(2) (1980).

The 45-day period in UCC $\$ 9-301$ (4) points in a different direction from the 45 -day period in the Federal Tax Lien Act. The former is a period of absolute protection for future advances that may be extended beyond $\mathbf{4 5}$ days until the secured party learns of the lien; the latter, however, marks the outer bound of protection for future advances against the tax lien, with knowledge of the lien that may come to the secured party even before the period has run destroying the priority of any subsequent future advances vis-a-vis the tax lien. This may be an instance of imperfect legislative docking. Imperfect docking is discussed in more detail in Part III C of this article. For an alternative interpretation, see Phillips, Flawed Perfection: From Possession to Filing under Article 9-Parts I and II, 59 B.U.L. REV. 1, 209, 230-34 (1979).

35. See id.

36. See infra notes 12-13.

37. See Requests for Comments, Exchange Act Release No. 21186 , Fed.-Sec. L. Rep. (CCH) If 83,648 (July 30, 1984); Advance Notice of Regulation of Foreign Futures Transactions in the United States, [1984-1986 Transfer Binder] Comm. Fut. L. Rep. (CCH) $\uparrow 22,279$ (July 25, 1984). 
American stock exchanges to allow trading in each other's listed stocks ${ }^{38}$ and comparable agreements between domestic and foreign commodities exchanges permitting settlement on one exchange of trades that have been executed on another. ${ }^{39}$ The scope of securities and commodities transactions has truly transcended the reach of local governing laws, and the growing disparity between the two has highlighted the significance of the lack of uniformity of the substantive law, ${ }^{40}$ the lack of personal jurisdiction of a court or regulatory body over all parties engaged in a transaction, ${ }^{41}$ and the difficulty of enforcement of any judgment or regulatory order even if personal jurisdiction over a subject is assertable. The legal strategems adopted or suggested to minimize these shortcomings, including the terms of the agreements between American and foreign exchanges, are patently secondbest solutions; the currently unattainable ideal is a supranational governmental authority that could enact and enforce securities and commodities legislation coterminous with the transactions involved. ${ }^{42}$

Historiographers rightly warn us of the risks of interpreting historical events in light of present-day experiences. Historical analogy poses especially difficult problems when a long period-say, several centuries-separates the analogical subjects. Nonetheless, current problems can at least suggest to us the kinds of considerations that might have inclined the framers of the Constitution to insert such provisions as the interstate commerce clause ${ }^{43}$ and the full faith and credit clause ${ }^{44}$ into the Constitution. In 1787, when the Constitutional Convention met, and increasingly for the next two centuries, probably no subject has more compellingly required the sameness of substantive law throughout the United States, personal jurisdiction by courts over all the parties to a transaction, and enforceability of judgments in every other jurisdiction than has the nation's expanding commerce. ${ }^{45}$

38. See Wall St. J., Aug. 31, 1984, at 2, col. 3 .

39. See Summary of the Proposed System of Mutual Offset Between the Chicago Mercantile Exchange and the Singapore International Monetary Exchange, Ltd., at 2 (Chicago Mercantile Exchange 1984); CFTC Approves U.S.-Singapore Link; Expands Trading Day in Three Contracts, 16 SEC. REg. \& L. REP. (BNA) 1457 (Aug. 31, 1984).

40. See generally 10A H. Bloomenthal, International Capital Markets and Securities Regulation 6-4 (1982); Thomas, Internationalization of the Securities Markets: An Empirical Analysis, 50 Geo. Wash. L. Rev. 155 (1982).

41. See, e.g., World-Wide Volkswagon Corp. v. Woodson, 444 U.S. 286 (1980) (held that Oklahoma could not exercise personal jurisdiction over a foreign defendant whose only contact with state was the fact that an automobile it had elsewhere sold was involved in an accident in Oklahoma); Commodities Futures Trading Comm'n v. Nahas, 738 F.2d 487 (D.C. Cir. 1984) (held that a district court could not enforce the service of subpoena by the Commodities Futures Trading Commission on a foreign national in a foreign country). See also Hacker \& Rotunda, The Extraterritorial Regulation of Foreign Business under the U.S. Securities Laws, 59 N.C.L. REv. 643 (1981); Rock, Regulatory Control over the United States, Canadian and United Kingdom Futures Markets, 37 Bus. Law. 613 (1982).

42. Cf. Mosler, Supra-National Judicial Decisions and National Courts, 4 Hastings Int'L \& Comp. L. REV. 425 (1981) (justifying the need for a international judicial body on similar grounds).

43. U.S. Const., art. I, §8.

44. Id., art. IV, \& 1 .

45. As Professor Gunther has noted, "That congressional power [the commerce power] ... was designed to promote a national market and curb Balkanization of the economy ...." G. GUNTHER, supra note 25, at 113. Another scholar is even more emphatic. Professor Crosskey has quite painstakingly argued that the national commerce power was originally meant to be complete rather 
Properly seen, then, uniform state legislation is nothing but an artful contrivance that is intended to substitute for genuine national legislation. It is a second-best rather than a first-best response to the need for nationwide uniformity. 66 To illustrate the deficiency of the uniform state law approach, consider, more particularly, the variations in article 9, that part of the Uniform Commercial Code with which this article is concerned-even ignoring for the moment the variations invited by section 9-401, which concerns the appropriate place of filing within a state.

In those jurisdictions that have adopted the 1972 or 1977 amendments to article 9, more than ten have enacted nonconforming amendments to sections

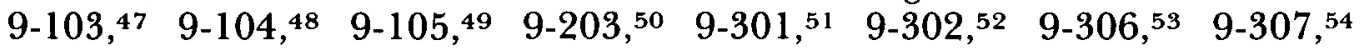

than interstitial. See generally W. CrosskeY, supra note 4, at 173-86. It is interesting to note that while Professor Crosskey's approach to the Constitution has been well criticized, see, e.g., Hart, The Relations between State and Federal Law, 54 Colum. L. Rev. 489, 500 n.28, 501 -02 (1954); Wechsler, The Political Safeguards of Federalism: The Role of the States in the Composition and Selection of the National Government, 54 Colum. L. Rev. 543, 544 n.l (1954), the critiques do not seem to take issue with his thesis that Congress's powers under the commerce clause were intended to be complete.

46. One cannot but note the irony that Erie R. Co. v. Tompkins, 304 U.S. 64 (1938), which is best defended as conducing to uniformity of law, see Friendly, In Praise of Erie-and of the New Federal Common Law, 19 Rec. A.B. CrTy N.Y. 64 (1964), overruled Swift v. Tyson, 41 U.S. (16 Pet.) 1 (1842), which Justice Story justified in light of the need for uniformity in commercial law. Not coincidentally, then, Judge Friendly, who defended Justice Brandeis's Erie opinion so vigorously against its critics, also wrote approvingly of the concept of federal commercial law:

Finally, what of the subject about which Mr. Justice Story was primarily thinking when he wrote Swift v. Tyson-commercial law? Here the effort for uniformity, once the limited value of Story's approach was recognized, has taken the form of an endeavor to secure the passage of various uniform acts, and now of the Uniform Commercial Code. The difficulty in getting uniform acts adopted by fifty state legislatures, the even greater difficulty in getting them adopted uniformly, the sheer impossibility of getting unruly judges to interpret them uniformly, and the felt necessity of resisting desirable amendments in order to protect the uniformity so hardly won, do not require elaboration. The remedy is obvious if it does not have undesirable side effects-federal enactment of the Uniform Commercial Code .

Friendly, supra, at 90 . It is also interesting to note that Judge Friendly seemed to think that Congress could pass a comprehensive federal statute applicable to all commercial matters, including intrastate transactions, within the United States:

Should such a federal act apply only to transactions where the papers or the goods they represent cross state lines? Should it exhaust the commerce power by one of the traditional wordings ....? Should it go even further and also include all commercial contracts with the Federal Government, all such contracts sought to be enforced in admiralty or bankruptcy, even all such contracts passing through the mails? Or should Congress take the still bolder step of declaring that, in order to make its rule truly workable in these large areas of its enumerated powers, the small remaining enclaves must also be occupied?

Id. See also supra note 45.

47. These jurisdictions include Alabama, the District of Columbia, Georgia, Indiana, Iowa, Maine, Massachusetts, Nebraska, New Hampshire, New Jersey, New Mexico, New York, Oklahoma, Rhode Island, Tennessee, California, Colorado, Delaware, Guam, Idaho, Montana, and South Dakota.

A word about the methodology used to determine the jurisdictions identified in this and succeeding footnotes is in order. Mr. Claude d'Estree, class of 1988 at Northeastern University School of Law, compiled the lists of jurisdictions, using as his primary source material the Uniform Commercial Code Reporting Service (Callaghan \& Co., Jan. 1986). Although this service does identify nonconforming amendments to the official text that have been enacted by different jurisdictions, it does not explicitly identify which official text (the 1962, 1972, or 1978 edition) the jurisdiction is presently using. To determine which official text a jurisdiction was using, Mr. d'Estree consulted the statutes of the various states rather than the Uniform Commercial Code Reporting Service. Using the state statutes, he first determined whether the jurisdiction had adopted section 9 . 
9-312,55 9-913,56 (despite the great effort made to achieve uniformity by amending 9-313 quite radically in the 1972 text $^{57}$ ), $9-402,589-403,{ }^{59} 9-404,{ }^{60}$ $9-405,{ }^{61} 9-406,{ }^{62} 9-407,{ }^{63} 9-408,{ }^{64}$ and $9-504 .{ }^{65}$ In addition, between five and

307(3)—and if not, the jurisdiction was classified as still using the 1962 edition. If a jurisdiction had adopted section 9-307(3), however, he then determined whether certificated securities were excluded from the instruments covered by section 9-305-and if they were, the jurisdiction was classified as having adopted the 1978 edition; if not, the jurisdiction was classified as having adopted the 1972 edition.

48. Alabama, Georgia, Hawaii, Indiana, Maine, Massachusetts, New York, Ohio, Pennsylvania, Rhode Island, California, Colorado, Guam, Minnesota, and Virginia.

49. Alabama, Arizona, Connecticut, the District of Columbia, Georgia, Hawaii, Illinois, Mississippi, New Jersey, New York, North Carolina, Ohio, Rhode Island, Tennessee, California, Guam, Minnesota, Oregon, Texas, and Virginia.

50. Alabama, Arizona, California, Colorado, Connecticut, Delaware, the District of Columbia, Georgia, Guam, Hawaii, Idaho, Illinois, Indiana, Iowa, Kentucky, Massachusetts, Michigan, Minnesota, Montana, Nebraska, New Hampshire, New Jersey, New Mexico, New York, North Carolina, North Dakota, Ohio, Oklahoma, Oregon, Pennsylvania, Rhode Island, South Dakota, Tennessee, Texas, Vermont, Virginia, and West Virginia.

51. Alabama, Arizona, California, Georgia, Guam, Illinois, Indiana, Iowa, Kentucky, Michigan, Minnesota, Montana, Nebraska, New York, North Carolina, North Dakota, Oklahoma, Oregon, Pennsylvania, South Dakota, Tennessee, Texas, Virginia, and West Virginia.

52. Alabama, Arizona, California, Colorado, Connecticut, Delaware, the District of Columbia, Guam, Hawaii, Idaho, Illinois, Indiana, Iowa, Massachusetts, Michigan, Minnesota, Mississippi, Montana, Nebraska, New Hampshire, New Jersey, New Mexico, New York, North Carolina, North Dakota, Ohio, Oklahoma, Oregon, Pennsylvania, Rhode Island, South Dakota, Tennessee, Texas, Virginia, and West Virginia.

53. Alabama, Arkansas, California, Connecticut, Georgia, Guam, Illinois, Minnesota, Nebraska, Oklahoma, South Dakota, Tennessee, and Virginia.

54. California, Colorado, Delaware, Georgia, Guam, Illinois, Indiana, Iowa, Kentucky, Maine, Massachusetts, Michigan, Nebraska, New Hampshire, New Jersey, New Mexico, North Dakota, Ohio, Oklahoma, Rhode Island, Tennessee, and Texas.

55. Alabama, Arizona, California, Delaware, Georgia, Guam, Indiana, Iowa, Michigan, Minnesota, Montana, Nevada, New Jersey, New York, North Carolina, North Dakota, Oklahoma, Oregon, Texas, Virginia, and West Virginia.

56. Alabama, Arizona, California, Georgia, Guam, Hawaii, Idaho, Iowa, Michigan, Minnesota, Mississippi, Nebraska, Ohio, Oklahoma, Rhode Island, South Dakota, Texas, and Virginia.

57. See Reasons for 1972 Change, UCC \& 9-313.

58. Alabama, Arizona, California, Colorado, Connecticut, Delaware, the District of Columbia, Georgia, Guam, Hawaii, Idaho, Illinois, Indiana, Iowa, Kentucky, Massachusetts, Michigan, Minnesota, Montana, Nebraska, New Hampshire, New Jersey, New Mexico, New York, North Carolina, North Dakota, Ohio, Oklahoma, Oregon, Pennsylvania, Rhode Island, South Dakota, Tennessee, Texas, Vermont, Virginia, and West Virginia.

59. Alabama, Arizona, California, Colorado, Connecticut, Delaware, the District of Columbia, Georgia, Guam, Hawaii, Idaho, Illinois, Indiana, Iowa, Kentucky, Massachusetts, Michigan, Minnesota, Montana, Nebraska, New Hampshire, New Jersey, New Mexico, New York, North Carolina, North Dakota, Ohio, Oklahoma, Oregon, Pennsylvania, Rhode Island, South Dakota, Tennessee, Texas, Vermont, Virginia, and West Virginia.

60. Alabama, Arizona, California, Colorado, Connecticut, Delaware, the District of Columbia, Georgia, Guam, Hawaii, Idaho, Illinois, Indiana, Iowa, Kentucky, Massachusetts, Michigan, Minnesota, Montana, Nebraska, New Hampshire, New Jersey, New Mexico, New York, North Carolina, North Dakota, Ohio, Oklahoma, Oregon, Pennsylvania, Rhode Island, South Dakota, Tennessee, Texas, Vermont, Virginia, and West Virginia.

61. Alabama, Arizona, California, Colorado, Connecticut, Delaware, the District of Columbia, Georgia, Guam, Hawaii, Idaho, Illinois, Indiana, Iowa, Kentucky, Massachusetts, Michigan, Minnesota, Montana, Nebraska, New Hampshire, New Jersey, New Mexico, New York, North Carolina, North Dakota, Ohio, Oklahoma, Oregon, Pennsylvania, Rhode Island, South Dakota, Tennessee, Texas, Vermont, Virginia, and West Virginia.

62. Arizona, California, Colorado, the District of Columbia, Georgia, Guam, Hawaii, Illinois, Maine, Minnesota, Mississippi, Montana, Nebraska, Nevada, Ohio, Oklahoma, South Dakota, Tennessee, and Virginia. 
ten jurisdictions have enacted variant versions of sections $9-106,669-109,{ }^{67}$ 9-110,68 9-204,69 9-206,70 9-303,71 9-311,72 9-501,73 9-505,,74 and 9-507.75 Fewer variations have been enacted with respect to sections $9-102,{ }^{76}$ 9-107,77

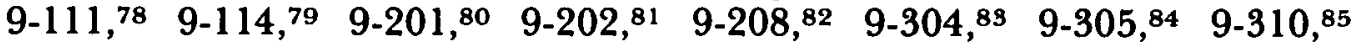
$9-314,869-318,879-503,88$ and $9-506.89$ Illinois has added a section to part 2 of article $9 ; 90$ Illinois and Texas have added a section to part 3 of article $9 ; 91$ twenty-seven states (including such key commercial states as California, New York, Pennsylvania, and Texas) have added sections to part 4 of article 9;92 and eight states have added sections to part 5.93 Finally, at least two states, North Carolina and Oregon, have added parts to article $9 .{ }^{94}$

63. Alabama, Arizona, California, Colorado, Connecticut, Delaware, the District of Columbia, Georgia, Guam, Hawaii, Idaho, Illinois, Indiana, Iowa, Kentucky, Massachusetts, Michigan, Minnesota, Montana, Nebraska, New Hampshire, New Jersey, New Mexico, New York, North Carolina, North Dakota, Ohio, Oklahoma, Oregon, Pennsylvania, Rhode Island, South Dakota, Tennessee, Texas, Vermont, Virginia, and West Virginia.

64. Connecticut, Hawaii, Idaho, Indiana, Maine, Michigan, Nebraska, New Jersey, Rhode Island, Tennessee, and Vermont.

65. Alabama, Arizona, California, the District of Columbia, Guam, Hawaii, Idaho, Iowa, Maine, Nebraska, Nevada, New Mexico, New York, Ohio, Oklahoma, and Texas.

66. Arizona, Hawaii, Nevada, Ohio, Oregon, and Tennessee.

67. Arkansas, California, Guam, Indiana, Kentucky, Maine, New Jersey, and Rhode Island.

68. California, Colorado, Guam, Mississippi, New York, North Dakota, South Dakota, and Vermont.

69. Iowa, New Jersey, North Dakota, Idaho, Minnesota, Montana, and South Dakota.

70. Colorado, Georgia, Nebraska, New Mexico, Oklahoma, Oregon, and Rhode Island.

71. California, Georgia, Guam, New York, and Ohio.

72. Arizona, California, Colorado, Oklahoma, and Guam.

73. California, Guam, Idaho, Nebraska, New Mexico, New York, Ohio, Pennsylvania, and Minnesota.

74. Alabama, Arizona, California, the District of Columbia, Guam, Idaho, Iowa, New Mexico, and Oregon.

75. California, Guam, Massachusetts, New Hampshire, and Oklahoma.

76. California, Georgia, Guam, and Iowa.

77. Tennessee.

78. California and Guam.

79. The District of Columbia and Maine.

80. Colorado.

81. South Dakota.

82. Arizona, California, Colorado, and Guam.

83. Arizona, New York, California, and Guam.

84. New York.

85. Alabama, Georgia, and Colorado.

86. Ohio, Rhode Island, and Vermont.

87. Connecticut and Ohio.

88. North Dakota, Pennsylvania, Vermont, and Colorado.

89. Iowa, Mississippi, Ohio, and Vermont.

90. See Ill. Rev. Stat. ch. 26, § 9-205.1 (1983).

91. See Ill. Rev. Stat. ch. 26, $\$ 9.307 .2$ (1983); Tex. Bus. \& Com. Code AnN. $\$ 9-319$ (Vernon Supp. 1987).

92. Alabama, Arizona, Arkansas, California, Connecticut, Florida, Hawaii, Indiana, Kansas, Maryland, Massachusetts, Michigan, Minnesota, Mississippi, Missouri, Montana, Nebraska, New York, North Dakota, Oklahoma, Oregon, Pennsylvania, South Dakota, Texas, Utah, Washington, and Wisconsin.

93. California, Kansas, Minnesota, Montana, North Carolina, Rhode Island, South Dakota, and Washington.

94. See N.C. Gen. Stat. \& 25-9-601 et seq. (1986); Ore. Rev. Stat. 79:6010 (Supp. 1985). 
Admittedly, the problem of uniformity is largely a matter of degree. It is better to have a Uniform Commercial Code, even with the above variations, operating in all fifty states, the District of Columbia, and United States territories, than to have instead fifty-odd more disparate versions of commercial law. In fact, many if not most of these noted variant amendments of the UCC are not materially substantive. Moreover, it might further be argued that the very volume of these amendments evinces a strong state interest in the law governing security interests in personal property, which would support a uniform state rather than a federal legislative approach to such transactions. But be all that as it may, the fact remains that owing to the number and range of these amendments, uniformity in the law governing security interests in personal property has been extensively impaired. Parties cannot know with certainty that the law that currently governs-or might be held in the future to govern-their transactions is-or will be-the same as the law with which they are most familiar. The scope of commercial transactions, especially secured transactions, has burgeoned beyond the law that is definitionally or arguably applicable to them.

Nor is this an easily rectifiable problem. Public choice literature informs that absent either a rule requiring unanimity for action or an ex ante rule binding all to the majority's choice, the greater the number of participant decisionmakers, the greater the number of choices likely to be made. ${ }^{95}$ With more than fifty different legislative bodies acting upon the official edition of the Uniform Commercial Code (whether we are speaking of the 1962, 1972, or 1978 edition), there is a significant probability that at least some will select variant resolutions to different commercial risk situations. One mode of decisionmaking that might avoid perhaps fifty different versions of the UCC would be to limit action on a particular edition to a "yea" or "nay" vote. Or it might be agreed ex ante that the version of a section accepted by a majority of decisionmaking bodies would be binding on all. Yet, it is precisely such alternatives that are precluded by a uniform state approach. In the absence of preemptive federal legislation, nothing prevents a state from enacting those statutory provisions it wants, provided they do not unreasonably constrain interstate commerce. Moreover, the ability of a majority of state legislatures to bind a minority violates the notion that uniformity may be effected only through voluntary acquiescence by each state in the substance of the proposed uniform legislation.

The preceding discussion, if anything, probably minimizes the public choice problems actually posed. Each state legislature, with one exception, ${ }^{96}$ is composed of two bodies, the members of which may feel strongly about different aspects of the Uniform Commercial Code. For example, some may entertain pronounced opinions about the priority of security interests in fixtures, the subject matter of section 9-313, while others may be more

95. See D. Mueller, Public Choice (1979). For an application of public choice theory in a legal context, see Easterbrook, Ways of Criticizing the Court, 95 HARv. L. REv. 802, 811 -31 (1982).

96. Nebraska has a unicameral legislature. 
concerned that a certain kind of transaction be excluded from article 9 by an amendment to the official version of section 9-104. Although it might be argued that this problem could also arise under a federal approach-for there are some 500-odd senators and representatives-there is an important difference. Idiosyncratic amendments to the UCC are barely visible at the state level unless and until they occur; but since national attention is riveted on the congressional process, such amendments would be less likely to pass through unobtrusively.

Lack of uniformity among the states in the law governing commercial transactions imposes substantial costs even if the similar aspects of their laws dwarf their dissimilarities. Commercial parties can work within the confines of almost any legal regime, provided only that they are certain of the outcome ex ante. But the particular idiosyncratic amendments of various states are not so easily detected, analyzed, and contractually avoided. Nor, since we are speaking of article 9 , is the answer simply to allow commercial parties to designate the law of a particular jurisdiction with which they are most familiar. Article 9, as all of personal property security law, is premised on the need to protect third parties-its terms cannot simply be circumvented by different contractual provisions as can, for example, the terms of delivery ${ }^{97}$ or payment $^{98}$ in article 2.

Of course, certainty of law can be achieved at some price. Lawyers can and do research state variations and advise their clients accordingly. But other matters being equal, it surely is disadvantageous so to structure a system that a lawyer is required to detect and analyze disparities when an alternative structure for achieving sameness of commercial law is available. Legal research takes time, and time is a cost that increases the price of credit and thereby decreases its overall availability at the margin. And, in fact, commercial law casebooks are replete with cases where adequate research was either never conducted or failed to lead parties to take those steps necessary optimally to protect their interests. ${ }^{99}$

\section{Ease of Amendment}

Commerce changes over time, and there is reason to believe that the pace of change has been accelerating. And as the form of transactions and the risks that inhere in them change, so must the law change; the alternative-change of commercial practice without correlative change of the applicable governing law-introduces or enhances the irrelevance of law to the real world. How do our two approaches to commercial law compare on this score?

97. See, e.g., UCC $\$ \S 2-319$ to $2-323$, which uniformly use the expression "unless otherwise agreed."

98. See id. See also UCC § 2-511(1) ("Unless otherwise agreed tender of payment is a condition to the seller's duty to tender and complete any delivery.").

99. See, e.g., Matter of Hammons, 614 F.2d 399 (5th Cir. 1980) (failure to file in correct county); United States v. Antenna Systems, Inc., 251 F. Supp. 1013 (D.N.H. 1966) (failure to specify that general intangibles were included as collateral); In re Leasing Consultants, Inc., 486 F.2d 367 (2d Cir. 1973) (failure to classify collateral correctly resulting in failure to file in correct state). 
One can answer this question by considering and contrasting such legislation as the Bankruptcy Code and its course of passage ${ }^{100}$ - which may be analogized to an amendment process, since the Code replaced its predecessor, the Bankruptcy Act-with the reworking of the Uniform Commercial Code that we have witnessed for the past twenty-five years. The legislative history of the Bankruptcy Code began with hearings of the Senate Judiciary Committee in 1968 to determine whether a commission should be created to study the Bankruptcy Act. Thereafter, Congress created such a commission, which then proceeded to conduct its own deliberations and publish its own recommendations. This report was followed by the introduction of bills in both the House and Senate, beginning in 1973, further congressional hearings and reports over the next five years, and final passage of the Bankruptcy Code in 1978. As Kenneth Klee has so aptly recorded for our benefit, "Pub. L. No. 95-598 the Bankruptcy Code is the culmination of ten years of effort involving hundreds of participants."101

Indeed, because the Bankruptcy Code constituted a wholesale revision of a body of law, its legislative history arguably is more appropriately comparable to the process of drafting rather than amending the Uniform Commercial Code. Approximately two decades rather than one, however, elapsed between the charge of the Uniform Laws Commissioners to Professor Llewellyn to revise the Uniform Sales Act and the eventual production of the 1962 edition of the UCC. ${ }^{102}$ But should the Bankruptcy Code's legislative course be used as a measuring rod for comparing an amending rather than a drafting process, the problematic nature of the uniform amending process is just as clearly evident. As of the beginning of 1986, approximately fourteen years after the 1972 amendments were promulgated, ten states had still not adopted those amendments. ${ }^{103}$ And, eight years after the 1977 amendments were proposed, a mere ten states had adopted them. ${ }^{104}$

The cumbersome nature of the amendment process is not inconsequential. In earlier discussing the lack of uniformity, I alluded primarily to the disparities among the several jurisdictions that had adopted the same version of the Uniform Commercial Code, most notably the 1972 edition. The problem of lack of uniformity is further exacerbated, moreover, by the fact that not every relevant jurisdiction is even working from the same edition of the UCC.

100. For a general and fairly concise legislative history of the Bankruptcy Code, see Klee, Legislative History of the New Bankruptcy Code, 54 AM. BANkr. L.J. 275 (1980).

101. See id. at 277.

102. See supra note 8.

103. Alaska, Florida, Kansas, Maryland, Missouri, South Carolina, Vermont, Washington, Wisconsin, Wyoming, and the Virgin Islands.

104. Arkansas, California, Colorado, Delaware, Guam, Idaho, Minnesota, Montana, Oregon, South Dakota, Texas, Virginia, and West Virginia. 


\section{Legislative Competence}

Although the federal approach may offer advantages vis-a-vis the uniform state approach in terms of legal authority, uniformity, and easier amendability, the fact is that in making a choice, we are not writing on a clean slate. The constitutional reason that best explains the origins of state legislative activity in the commercial law field no longer presents an obstacle to federalization, but the by-product of this constitutional history-long legislative experience among the states with the subject matter of commercial law, including secured transactions-may be thought, in itself, powerfully to argue in favor of retaining the uniform state approach. Thus, today, rather than being tendered on the basis of now-discarded constitutional doctrine, the deference-to-state-judgment argument is more apt to be based on the closer proximity of states to most transactions governed by article 9 , the long familiarity of states with the subject matter of commercial law, and the view that the federal legislative menu is already too full to permit the governance of commercial matters on an ongoing basis. ${ }^{105}$

No matter how the legislative competence argument is articulated, the value of state legislative judgments figures as an important supporting rationale. But except for the selection of Uniform Commissioners by each state, ${ }^{106}$ the reality is that the uniform state approach is clearly meant to preclude individual state legislative judgments on all but marginal matterssuch as the appropriate location for an article 9 filing within a state. Few, if any, knowledgeable persons would really favor states, on the basis of their allegedly superior expertise in matters commercial or their familiarity with the historical record, passing nonconforming amendments to article 9.

Is it not possible, however, that a superior legislative competence is manifested precisely in states' passage of nonconforming amendments? ${ }^{107}$ Although the drafters might originally have regarded a certain resolution of a particular issue to have been optimal, in practice, the nonconforming amendment might prove to be preferable. And when this is the case, the nonconforming amendment can then be coopted by the Permanent Editorial Board and recommended for adoption by other states. According to this view, then, variations in the law may be a blessing in disguise-admittedly generating some costs, but also fostering valuable offsetting benefits.

Whether real or idealized for the sake of supporting a uniform state approach, this more favorable view of lack of uniformity reflects Justice Brandeis's conception, expressed in New State Ice Co. v. Liebmann, ${ }^{108}$ of states as laboratories, experimenting with different laws. In the words of Henry Hart, "a political system which maximizes the opportunities for coping

105. See Kennedy, supra note 6 , at 1227.

106. For a description of the operation and history of the Uniform Commissioners, see Dunham, A History of the National Conference of Commissioners on Uniform State Laws, 30 LAW \& ConTEMP. ProBs. 233 (1965).

107. For an expression of this view, see Kennedy, supra note 6, at 1233.

108. 285 U.S. 262 (1932). 
effectively with the problems of social living is better than one that minimizes them. This means a federal system." 109 But however appealing the BrandeisHart perspective may be with respect to private law generally-that is, the benefits of experimentation at the state law-making level exceed the costs of the resulting lack of uniformity nationwide-the argument is quite tenuous when applied to the Uniform Commercial Code in general and article 9 in particular. Most importantly, section 1-102 pointedly states that one of the three most important "underlying purposes and policies of the [UCC] is to make uniform the law among the various jurisdictions." 110 In short, the deference to state authority characteristic of uniform state legislation is more a matter of style than of substance. Such deference would hardly be desirable in the case of legislation that must apply uniformly to all transactions within the United States. It seems somewhat disingenuous, then, to argue that lack of uniformity qualifies as a benefit rather than a cost of a uniform state as compared to a federal approach. Because we do not want nonconforming amendments, the conversion of a cost of a uniform state approach into a purported benefit smacks strongly of sophistry.

Moreover, the nonconforming amendments that have been adopted by states and later coopted by the Permanent Editorial Board as part of the official version of the Uniform Commercial Code have often been recommended primarily because their adoption would again make the UCC more uniform, not necessarily because their substance truly represents a preferable solution to a particular risk-bearing problem. Consider, for example, the most notorious of these amendments, the 1972 version of section 9-313. Although the last two paragraphs of the Reasons for 1972 Change pay homage to the political desirability of the amendment on grounds other than reestablishing uniformity, the bulk of the Reasons more forthrightly acknowledges that in light of the failure of California and Iowa to adopt the 1962 version of section $9-313$ and the relatively successful efforts of other states to amend it, the overriding goal of uniformity required closer conformation of this section to the expectations of the real estate bar. ${ }^{111}$ Still, many, if not most, of the sections affected were improved by the 1972 amendment. ${ }^{112}$ For example, consider future advances, the changed treatment of which had been suggested by operational history under the 1962 version of article 9. It is such practical experiences, which know no state boundaries, that are truly assimilable to experiments by which ideas are tested-and they would have occurred under federal just as under uniform state legislation.

In legal literature of the past decade, an effort has been made to validate Justice Brandeis's state-laboratory thesis as a model of economic efficiency. Different states compete for legal jurisdiction over individuals, other legal

109. See Hart, The Relations between State and Federal Law, 54 Colum. L. Rev. 489, 542 (1954).

110. UCC \$ 1-102(2)(c).

111. See Reasons for 1972 Change, UCC $\$ 9-313$.

112. Id. § 9-312. 
"persons" such as various kinds of enterprises, and transactions. ${ }^{13}$ The states win or lose this competition depending upon the degree to which their legal regimes facilitate or retard transactions. In contrast, it is noted, the federal government competes with no other entity. Presumptively, then, state solutions are efficient-otherwise they would not have survived in the competitive legal world-while federal legal solutions are inefficient. ${ }^{114}$ The comparisons expressly or impliedly invoked are: first, to the product, capital, and other markets in which business enterprises compete (markets that produce resolutions closer to Kaldor optimal than would be achieved in a state-directed business environment); and, second, to the Darwinian competition among biological forms of life in which the fittest survive. Although there is, indeed, some persuasive force to these metaphors in certain substantive areas of the law, the movement from premise (states have competitors, but the federal government has none) to conclusion (presumptively, state solutions are efficient, while federal solutions are not) is far too facile. This linguistic exercise begs the hard questions. Does not the federal government compete in a world of legal jurisdictions? And if the argument is limited to the claim that the states compete more extensively than does the federal government, why not argue normatively for county, city, or even township legislation, since this would generate even more competition and thus conduce to even greater efficiency?

Stripped of perhaps distracting analogies, the significance of a nexus between varied legal possibilities and efficient transactions in the real world may be seen to turn upon which of two models of law-one facilitative and the other regulatory-should obtain. The primary purpose of facilitative law is, as the term implies, to ease the consummation of transactions. Frequently, this facilitative function takes the form of offering off-the-shelf standardized rules that save transacting parties the expense of specifying these rules in their contracts-although nothing prevents the parties, in unusual cases, from specifying other terms that may be more suitable to their circumstances. The regulatory model of law, in contrast, presupposes a more activist governmental stance. The lawmaking body does not simply offer standardized rules subject to such modification as the parties may desire; rather, it must prescribe rules by which the parties necessarily will be bound.

In commercial transactions generally, the facilitative seems clearly preferable as the dominant model-otherwise, what remains of the rationale for capitalism, with the inevitable inequities that it tolerates? But a general preference for the facilitative model hardly necessitates rejection of regulation in specific contexts. And article 9 is generally considered to be such a special context-so much so that some scholars, including Professors Douglas Baird

113. See, e.g., Winter, State Law, Shareholder Protection, and the Theory of the Corporation, 6 J. LEG. STUD. 251 (1977) (states as competing in the market for corporate charters).

114. See, e.g., Easterbrook \& Fischel, Mandatory Disclosure and the Protection of Investors, 70 VA. L. REv. 699 (1984) (arguing that state corporate law is presumptively efficient, while federal securities law is not). 
and Thomas Jackson, have argued that various forms of transactions that are not currently assimilated to secured transactions and subsumed under article 9 should, nonetheless, be subjected to its filing requirements. ${ }^{115}$ Without necessarily agreeing with Professors Baird and Jackson's specifics, it can be argued that the larger framework into which their proposals fit presupposes that personal property security law exists for the protection of third parties. Indeed, the raison d'etre of all creditor-protection law, including that of personal property security law, requires choice of a legal structure having at least some regulatory characteristics.

Moreover, it seems inaccurate automatically to equate federal law with a regulatory and state law with a facilitative model. Commercial law, whether legislated via a federal or a uniform state approach (or, for that matter, a nonuniform state approach), can offer parties various options for transacting, thereby allowing them to choose the course that is best for them. Law can also supply presumptions that operate among these various choices, specifying those terms that the parties would probably have independently selected. Commercial parties are thereby able to avoid or reduce the transaction costs otherwise borne in explicitly contracting about the same matters. Indeed, this mode of facilitating transactions has been adopted by the Uniform Commercial Code in the price and delivery terms specified in sections 2-319 through 2-324, the risk-of-loss provisions of sections 2-519 and 2-510, and numerous other contexts. And where this facilitative model is appropriate-in other words, where third-party interests are not implicatedit can be implemented regardless of whether the federal or the uniform state approach is adopted.

Finally, it should again be noted that one of the most facilitative aspects of law is its easy accessibility and relative certainty. Thus those who favor a facilitative approach as the dominant influence on a particular body of substantive law should recognize that confusion over legal references, which poses a more substantial risk under a uniform state than under a federal approach, can at some point become so great that the expenditure necessary to discover the law inhibits transactions.

\section{E. Judicial Competence}

The question of judicial competence, broadly defined, might also initially be thought to cut both ways. On the one hand, one probably finds fewer adherents of a Brandeisian view of experimentation at the judicial level-for federal judges, given the different circuits, seem fully capable of experimenting with different legal approaches to the same problem when plausible conflicting or supplementary views do exist. Furthermore, it is generally perceived-although not necessarily true-that the greater

115. See Baird \& Jackson, Possession and Ownership: An Examination of the Scope of Article 9, 35 Stan. L. REv. 175 (1983). 
prestige-and in some cases, the greater pay-has resulted in a better qualified and hence more competent federal than state judiciary.

On the other hand, however, the congested state of the federal docket has been well publicized, and further expansion of the courts' workload will intuitively appear to some to be the greatest cost of federalizing personal property security law, whether or not it is integrated with the Bankruptcy Code. Indeed, the consequent aggravation of an already disturbing bottleneck in the judicial system, it might be argued, would aid neither the general cause of justice nor that of secured parties and other creditors who, like most other litigants, want their disputes handled expeditiously.

Less intuitively apparent, however, is the extent to which, on a judicial level, the law of personal property has already become federalized. A perusal of volume 40 of the Uniform Commercial Code Reporting Service, 116 the latest bound volume of this reporter available at the time of this writing, reveals that 132 cases primarily concerned article 9 rather than other articles of the UCC. Of these cases, eighty-three-or sixty-three percent of the total-were decisions of federal courts, while only forty-nine-or thirty-seven percent of the total-were decisions of state courts. Although there is no guarantee that volume $\mathbf{4 0}$ contains an accurate representative sampling of all reported article 9 cases, there also is no reason to believe otherwise, particularly in the period since the institution of the bankruptcy courts, either as created in the 1978 Bankruptcy Code or its 1984 amendments ${ }^{117}$ dealing with the consequences of Northern Pipeline Construction Co. v. Marathon Pipeline Co. ${ }^{118}$ Admittedly, there is also no assurance that all decisions, both reported and unreported, in which article 9 questions arose reflect the same percentage terms; but since both state and federal decisions frequently go unreported for a variety of reasons, a more complete, yet practically unattainable, picture would probably not appreciably alter the statistic that nearly two-thirds of all article 9 cases are already decided in federal courts.

Regardless of the statistics, however, nothing precludes Congress from tailoring federal jurisdiction as it chooses. For example, were the subject matter of article 9 to be federalized and integrated with the Bankruptcy Code, Congress might well set a minimum dollar amount in nonbankruptcy cases that would have to be met before the federal courts would have jurisdiction in the matter; otherwise, state courts would handle the controversy even if the law involved were federal.

\section{F. The Notice-Filing System}

Much of the tilting in favor of a federal approach to commercial transactions relates to the greater variability of law that inheres in a uniform

116. David Bunker, a student in the class of 1986 at Northeastern University Law School, compiled the statistics that follow in the text during the Winter 1985-86 quarter.

117. Bankruptcy Amendments and Federal Judgeship Act of 1984, Pub. L. No. 98-853, 98 Stat. 333 el seq. (1984).

118. 458 U.S. 50 (1982). 
state approach. But article 9 is particularly concerned with third-party protection, which is primarily provided by that article's notice-filing system; and in contrast to their position with respect to most other aspects of article 9 , the drafters here specifically acquiesced in state variations of filing requirements. ${ }^{119}$ Some states require centralized filing exclusively in the office of the Secretary of State, excepting only fixture filings; other states require filing at the county level, either alone or in conjunction with centralized filing, depending upon the nature of collateral. ${ }^{120}$ The drafters' amenability to local filing reflected the belief of some "that most credit inquiries about local businesses, farmers and consumers come from local sources; convenience is served by having the files locally available and there is not great advantage in centralized filing."121

But the sanctioning of alternatives for filing on a state-by-state basis should not obscure the drafters' own preference. Certainly a fair reading of the Official Comment to section 9-401, from which the above quotation about "local businesses" has been drawn, indicates that the drafters clearly preferred centralized filing: "The more completely the files are centralized on a state-wide basis, the easier and cheaper it becomes to procure credit information; the more the files are scattered in local filing units, the more burdensome and costly."'122

If anything, experience suggests that the drafters underestimated the full costs of both localized filing and the peculiar variations exhibited among the several states. The difficulties posed for the party required to file have included the possibility that he may file in the wrong county; ${ }^{123}$ or that he may file at the state level but forget to file at the county level, ${ }^{124}$ or vice versa; ${ }^{125}$ or that he may neglect to refile as the location of the collateral changes. ${ }^{126}$ Moreover, a secured party may fail initially to file in the correct place because of having misclassified the nature of the debtor's property interest. ${ }^{127}$ From the perspective of the party who wants to search for possible prior security interests in the debtor's property, the principal shortcomings of localized filing stem from the collateral-based nature of the filing requirements. ${ }^{128}$

Thus, article 9's filing system would be problematic even had the drafters not validated any local filing, but rather had insisted on the exclusivity of centralized filing with respect to security interests in all collateral except

119. UCC \$9-401. Compare First Alternative subsection (1), with the Second and Third Alternatives.

120. See the three alternative versions of UCC $\$ 9-401$.

121. Id. Comment 1.

122. Id.

123. See Matter of Hammons, 614 F.2d 399 (5th Cir. 1980).

124. See, e.g., Package Machinery Co. v. Cosden Oil \& Chemical Co., 51 A.D.2d 771, 380 N.Y.S.2d 248 (1976).

125. See, e.g., Cain v. Country Club Delicatessen, 25 Conn. Supp. 327, 203 A.2d 441 (Super. Ct. 1964).

126. In re Utah Agricorp, 12 B.R. 573 (Bankr. D. Utah 1981).

127. See, e.g., In re Leasing Consultants, Inc., 486 F.2d 367 (2d Cir. 1973).

128. See Phillips, supra note 34 , at 210-22. 
fixtures. As I have detailed elsewhere, ${ }^{129}$ the transactions of most parties affected by the filing system relate primarily to the debtor rather than to the collateral; only infrequently do their transactions relate more to the collateral than to a debtor from whom repayment of a debt or satisfaction of a judgment is sought. Accordingly, a location-of-collateral as opposed to location-ofdebtor filing system has complicated the dealings of third parties with the debtor and made the task of discovering prior security interests in his personal property more difficult.

In contrast, a federal approach to personal property security law suggests a national filing system that would obviate any need to distinguish between a location-of-debtor and location-of-collateral rule. Such an approach, rather than focusing upon which of many possible jurisdictions has the closest connection either to the collateral or to the debtor, would permit both the filing and the retrieval of relevant information from anywhere in the United States and would obviate the necessity of extensive research, with the attendant mailing of financing statements and information statements to multiple offices around the country. Current technology easily permits such a system.

It may, of course, be objected that nothing precludes the states from agreeing to and adopting a national filing system as part of a uniform approach. But the fact remains that they have not; nor, to the best of my knowledge, has it been suggested that they do so. In any event, even if most jurisdictions agreed to computerize filing on a national basis, they would still likely insist on some kind of state identification in that system-and at that point, secured parties required to file would be exposed to the same kind of risk of error they now encounter with localized filing. States are bound to insist upon such identification because without it, application of a particular state's version of the Uniform Commercial Code to the transaction in question would be perceived as less justified and thus become uncertain. And even if a uniform amendment to article 9 implementing a national filing system were proposed, the problems of amendment and local variation already identified in connection with other provisions of article 9 might still arise. For example, as long as some states still insisted on localized paper filings, some of the problems currently associated with such filings would persist.

Admittedly, certain problems would also attend a national computerized filing system, including accurate identification of the debtor, the possibility of fraudulent inputs, and excessive accessibility to the credit status of debtors. Without minimizing these or other potential problems-and with the caveat that the details of this proposal are at the moment less important than the concept-one may still observe that there is no reason why the tax identification number of a debtor (which, to the best of my knowledge, hardly ever changes) cannot serve to differentiate debtors along with their names-

129. See id. at 6. 
whether individual, corporate, or otherwise. Nor is it clear why the opportunity for fraudulent input would be any greater with a computerized system than with a paper system that currently requires only the debtor's purported signature. Finally, with respect to easy accessibility to the credit status of debtors, we must never forget that the ultimate objective of a noticefiling system is not notice, but knowledge of the security interests. ${ }^{130}$ Collectively, we are better off if interested parties know of other credit extensions to the debtor and can accurately determine the terms of their own projected dealings with the debtor in light of the risks presented. In short, the easier accessibility to credit information to which a national computerized filing system would conduce should, on balance, be counted as a benefit rather than a cost.

\section{G. The Separateness of Personal Property Security Law}

One quite natural reaction to my suggested federalization of personal property security law would be to inquire whether this would not also require the federalization of much additional law besides that currently covered by article 9. And if so, would not this proposal entail a much more radical redefinition of federal-state roles than may initially appear to be the case? Two specific bodies of law that might be implicated are other aspects of commercial law, especially those embraced in the remainder of the Uniform Commercial Code, and real property security law. Yet, while there may be arguments for federalizing these other bodies of law-and this article is not intended to negate that possibility-the factors we have hitherto considered simply do not militate as strongly in favor of such federalization as they do with respect to the law relating to personal property security interests.

Consider, first, the law relating to real property mortgages-concerning which a consensus in favor of uniformity-even at the state level-has not even begun to crystallize. Without such consensus, the choice of uniformity as a prime factor by which to adjudge the merits of a federal vis-a-vis a uniform state approach is itself problematic.

Consider, next, other aspects of commercial law, which, unlike the law relating to real property mortgages, are acknowledged to require a uniform treatment. These are, in the main, the subject matter of articles 2 (sale of goods), 3 (commercial paper), and 4 (bank deposits and collections) of the Uniform Commercial Code. Several differences between the subject matters of these articles and that of article 9 are apparent. Except in limited respects, such as warranty law-where the pressure for true uniformity is among those considerations that explain the passage of the Magnuson-Moss Warranty Act $^{131}$ - these articles have not been subjected to nonuniform amendment to the same extent as has been article 9. Also, there is no overriding focus of these articles comparable to a filing system, the operation of which has been

130. See Phillips, Formalist Trends in Commercial Law Scholarship (paper on file).

131. 15 U.S.C. $\$ \S 2301-2312$ (1982). 
hindered by a uniform state rather than a federal approach to the subject matter. And most significantly, these articles relate to the ex ante allocation of risks or the ex post allocation of losses in numerous contexts having nothing to do with the bankruptcy of one of the transacting parties. As the next section of this article makes clear, the same cannot be said of personal property security law, which integrally relates to the risk of insolvency. And the dominant body of law that governs in the insolvency context is the federal law of bankruptcy.

If these factors do suggest that the law of personal property security does meet the criteria we have discussed to a degree greater than do other key aspects of commercial law covered by the Uniform Commercial Code, ${ }^{132}$ is article 9 sufficiently separable from the other articles of the UCC to permit the federalization of only the former? The number of interacting sections between, for instance, articles 2 and 9 are relatively few-sections 2-326 and 9-114, dealing with consignments and similar transactions, and section 9-113, relating to security interests that arise under article 2, come to mind-and they are fewer than, say, the interactions between article 9 and the Bankruptcy Code. Nor would the separation of the subject matter of article 9 from the UCC's other articles destroy tightly coordinated cross-references and interactions. Section 9-113, for example, refers to security interests arising under the article on sales; but article 2, except in shipment contexts, never explicitly provides for a seller's lien, the apparent reference of section 9-113. Key terms in article 9-"instrument," 133 for example-are not even defined in the same way in which they are in other articles of the Code.

Parenthetically, the present generation of students may not realize and some commercial law scholars may tend to forget that at one time, personal property security law and other commercial law were the subjects of different legislation. Of course, no one would urge reinstatement of the various statutes that used to govern personal property security-for example, the Uniform Conditional Sales Act, the Uniform Trust Receipts Act, various chattel mortgage statutes, and the like. But if the question is whether the law of personal property security should inseparably be conjoined in the Uniform Commercial Code with other branches of commercial law, the countervailing strength of the relationship of personal property security law and bankruptcy law must be considered. It is this nexus that the next part of this article addresses.

To summarize, then, a uniform state as compared with a federal approach to commercial law, especially the law governing security interests in personal property, suffers from lack of uniformity (the very objective of the exercise), a

132. I exclude from this category ("other key aspects of commercial law covered by the Uniform Commercial Code") the law applicable to bills of lading, as that law has largely been federalized by the Federal Bills of Lading Act, 49 U.S.C. \$\$ 81 et seq. And surely the confusion that has been generated by applying federal law to interstate shipments and state law to intrastate shipments is less desirable than an approach that would-like my suggestion concerning the substance of article 9 of the UCC-completely federalize the law of bills of lading.

133. Compare the definition of "instrument" in $\S 9-105$ (1)(i) with its definition in $\S 3-102(1)(e)$. 
cumbersome amendment process, needless legal transactional costs, and a strong, although not inseparable, bond to a local rather than national filing system. State legislation, even where uniform, lacks the authority accorded to national legislation in our federal system. Given the degree to which the federal courts are already the key interpreters of this body of law, federalization of personal property security law-even if it expanded federal jurisdiction over commercial disputes-would not entail a wholesale reallocation of judicial resources in this area. And finally, although separation of the law of personal property security from what is conventionally regarded as the body of commercial law-the Uniform Commercial Code-might entail some costs, these would appear to be slight and must, in any event, be measured against the relatively greater costs that the federalization of the law of personal property security would avert.

\section{III}

\section{INTEgRation WITH THE Bankruptcy Code}

The federal character of bankruptcy law is a compelling additional reason to federalize personal property security law. In fact, such federalization should take the form of integrating personal property security law with the Bankruptcy Code. The proposal for integration relates to four factors: the essential relationship between the notion of a security interest and the risk of bankruptcy; the emission of inconsistent and sometimes competitive incentive signals by article 9 and the Bankruptcy Code; the phenomenon of "imperfect docking" between article 9, as state law, and the Bankruptcy Code, as federal law, despite obvious attempts at coordinating the two bodies of law; and, finally, the ability to tackle more directly certain fundamental questions once personal property security law and federal bankruptcy law are coordinated.

\section{A. The Nexus Between Secured Credit and the Risk of Bankruptcy}

The greatest risk against which a security interest is intended to protect the secured party is the debtor's insolvency. It seems almost axiomatic, then, that personal property security interest law is in function, if not in form, an aspect of the law related to bankruptcies and therefore should be part of it.

Several factors might be thought inconsistent with the asserted primacy of the personal property security interest-bankruptcy relationship. One is that article 9 protects the secured party against more than the risk of bankruptcy. Another is that the principal parties protected by the linchpin of article 9's construct, the filing system, are other secured parties, ${ }^{134}$ not lien or trade creditors, who are generally perceived as being more at risk in the event of the debtor's bankruptcy and for whom the protection afforded by the Bankruptcy Code was primarily intended.

134. For an example of such an argument, see Baird, Notice Filing and the Problem of Ostensible Ownership, 12 J. Legal Stud. 53 (1983). 
That personal property security law pertains to risks other than that of bankruptcy, however, cannot hide the reality that bankruptcy is the chief risk to which such law is directed. True, article 9 offers protection, in varying degrees, to the secured party vis-a-vis other secured parties, ${ }^{135}$ purchasers of the collateral and its proceeds from the debtor, ${ }^{136}$ lien creditors, ${ }^{137}$ and others. But owing to the countervailing protections accorded to some of these other competing interests-for example, purchasers of the collateral or proceeds in the ordinary course of business, ${ }^{138}$ or purchasers and possessors of chattel paper that is merely proceeds of collateral in which the secured party claims an interest ${ }^{139}$ - the secured party's interest, even if perfected, may be subordinated to such competing interests, if not extinguished entirely. The secured party who has perfected his security interest, then, is most completely protected against lien creditors and other secured parties who subsequently file or otherwise perfect their interests in the collateral-that is, he is most surely protected against the bankruptcy risk.

Factual experience seems to bear out this conclusion that bankruptcy is the paramount risk against which the security interest is designed to guard. Conflicts between a secured party and the bankruptcy trustee greatly outnumber those between secured parties outside of bankruptcy or between a secured party and a genuine lien creditor. Returning to the statistics drawn from volume 40 of the Uniform Commercial Code Reporting Service cited earlier, ${ }^{140}$ we noted that 83 of 132 cases dealing with article 9-or 63 percent-arose in the federal courts. Of those, 69-or 83 percent of the federal total-were bankruptcy cases at either the trial (the federal bankruptcy courts) or the appellate levels (federal district courts or courts of appeals). Even if the nonbankruptcy federal cases are added to the state cases, then, a majority of the article 9 cases related to the bankruptcy risk. Nor is there any reason to suppose that these proportions do not roughly reflect the risks against which secured parties have actually sought protection.

Secured parties extend credit to debtors and want payment. ${ }^{141}$ In the typical secured transaction, the collateral serves as a "security blanket," recourse to which is only a second-best resolution for the creditor. Focusing undue attention upon the protection afforded secured parties against purchasers of the collateral distorts the overwhelming concern of the secured party to be repaid. In contrast, focusing upon the secured party's desire to be protected against the bankruptcy risk places the role of collateral in its proper perspective.

\footnotetext{
135. See UCC § 9-312.

136. See UCC $\$ \$ 9-307,9-301(1)(c)$.

137. See UCC \$ 9-301(1)(b).

138. See UCC $\$ 9-307(1)$.

139. See UCC § 9-308(b).

140. See supra note 116 and accompanying text.

141. See Phillips, supra note 34 , at 6 .
} 
An interesting body of literature has arisen discussing why security interests exist in the first place, ${ }^{142}$ given the heuristic insight of Professors Franco Modigliani and M.H. Miller that a debtor's cost of capital should be constant, regardless of the make-up of that capital. ${ }^{143}$ Creditors can and do compensate for any risk through their terms of credit with the debtor, provided only that the risk is known and calculable. Hence, because the taking of security by some creditors must necessarily increase the risk of unsecured creditors, the latter will charge the debtor more for their credit as the former-the secured creditors-charge less. In the aggregate-and without further explanation-it is uncertain what has been gained.

To answer why secured credit exists, some have suggested a monitoring theme. ${ }^{144}$ If having a security interest provides that party best able to monitor with a positive incentive to monitor, ${ }^{145}$ or alternatively provides those creditors least able to monitor with a substitute for monitoring, ${ }^{146}$ and if others benefit from these monitoring and quasi-monitoring activities, then perhaps the aggregate cost to the debtor of credit-both secured and unsecured-will be less than the same amount of unsecured credit would have been.

But another answer to the question of why secured credit exists has also been suggested, and it is in some ways more persuasive than the monitoring explanation: A debtor's bankruptcy, to which secured credit largely responds, is so unpredictable and so costly that allaying the creditor's anxiety in this regard will reduce the debtor's overall cost of capital. ${ }^{147}$ And the uncertainty

142. See, e.g., Schwartz, The Continuing Puzzle of Secured Debt, 37 VAND. L. Rev. 1051 (1984); White, Efficiency Justifications for Personal Property Security, 37 VAND. L. Rev. 473 (1984); Levmore, Monitors and Freeriders in Commercial and Corporate Settings, 92 YALE L.J. 49 (1982); Schwartz, Security Interests and Bankruptcy Prionities: A Review of Current Theories, 10 J. Legal. STud. 1 (1981); Jackson \& Kronman, Secured Financing and Priorities Among Creditors, 88 YALE L.J. 1143 (1979).

143. See Modigliani \& Miller, Theory of Investment, The Cost of Capital, Corporation Finance and the Theory of Investment, 48 AM. Econ. Rev. 261 (1958).

144. See, e.g., Levmore, supra note 142; Jackson \& Kronman, supra note 142.

145. See Levmore, supra note 142, at 55-58. Professor Levmore, unlike Jackson \& Kronman, supra note 142, identifies the secured party as the most talented monitor and suggests that a decrease in the overall cost of capital might occur because others, particularly unsecured creditors, might then be able to freeride on the monitoring efforts of the secured party.

146. See Jackson \& Kronman, supra note 142, at 1158-61. Professors Jackson and Kronman choose the counterintuitive route and suggest that the parties who become secured parties, such as banks, are the least talented monitors. In effect, then, the security interest becomes a substitute for the monitoring activities in which other creditors, most notably trade creditors, are able to engage. Although creative, Professors Jackson and Kronman's suggestion has little basis in reality. Banks and other institutional secured creditors regularly review the financial statements of the debtor; few trade creditors do, although their extensions of credit, through the mediation of financial rating companies such as Dun \& Bradstreet, are ultimately based on the same financial statements as well as such other factors as their own and other trade creditors' experience with the particular debtor. And other secured creditors, such as purchase money secured parties, are clearly superior monitors. The machinery manufacturer or distributor who takes back a purchase money security interest will frequently play a role in servicing the asset sold. That servicing effort constitutes a monitoring effort.

147. See Castanias, Bankruptcy Risk and Optimal Capital Structure, 38 J. Fin. 1617 (1983) ("empirical results ... are consistent with the thesis that ex ante default costs are large enough to induce the typical firm to hold an optimum mix of debt and equity." Id. at 1629); Scott, Bankruptcy, Secured Debt and Optimal Capital Structure, 32 J. Fin. 1 (1977). But see Smith \& Warner, Bankruptcy, Secured Debt, and Optimal Capital Structure: Comment, 34 J. Fin. 247 (1979) (arguing that deterrence of asset substitution 
the creditor faces extends beyond the possibility of a debtor's bankruptcy to the uncertainty, if the debtor does become bankrupt, of the creditor's realization out of such a proceeding. The exceedingly wide variance of past outcomes makes prediction of future losses stemming from bankruptcy highly tentative and constantly amendable in light of new data. True, the creditor can reduce these uncertainties by diversification, but diversification's maximum prophylactic effect, even theoretically, is a reduction rather than an elimination of the costs associated with bankruptcy. The risk is systemic. Moreover, when we advance beyond normative models based on theory to the observed reality of various banks with respect to energy loans, third-world loans, and the like, loan portfolios may be much less diversified than we would probably expect-and certainly much less diversified than a stock portfolio that is intentionally structured to reduce the unsystemic risk in light of past statistics about various industries and corporations. In sum, although probably no one factor explains the existence and characteristics of secured credit in our society, ${ }^{148}$ surely among the most compelling explanations is the uncertainty associated with bankruptcy.

A second possible response to my suggestion that a security interest primarily relates to the bankruptcy risk could be based on Professor Baird's observation that article 9's filing system, the keystone of the perfection process, without which the secured party is ordinarily not protected against any of the third parties we have mentioned, is searched by other secured parties or potential secured parties and serves to protect them, not trade creditors and others. ${ }^{149}$ In truth, Professor Baird's observation needs to be empirically tested, but his model of creditor behavior seems excessively inflexible. Quite obviously, if security interests affect the risk of trade creditors and others, their relative inexpertise (as compared, arguably, with that of banks and other financial institutions) in searching the filing system and adjudging credit risk on the basis of those filings disclosed still would not diminish their ultimate reliance upon such filings. Trade creditors do rely upon firms in the business of assessing credit risk such as Dun and Bradstreet. And, indeed, these credit institutions do search filing systems, and their discoveries are among the important data transmitted to trade creditors in their credit ratings of various debtors.

In any event, even were Professor Baird to be proven correct, the question of which third parties take advantage of the filing system is distinct from the question of which risks secured parties are primarily seeking to minimize.

is the best explanation for secured credit). A variant nexus between the bankruptcy risk and an explanation for secured credit is that unsecured creditors, given the bankruptcy risk and the possibility that statutory priorities will wipe out their prospect of being paid more than a small fraction of their claims, will be somewhat indifferent to a security interest covering some or all of a debtor's assets. If so, the aggregate cost of credit will be lower if the debtor grants security interests to certain creditors, thereby decreasing the cost of credit they extend, and not to others, who will not raise their cost of extending credit proportionately. See White, supra note 142, at 481-89.

148. See D. Baird \& T. Jackson, Security Interests in Personal Property 360-67 (1984).

149. See Baird, supra note 134. 
Professor Baird's observation that only other secured parties or potential secured parties directly check for filed financing statements is not necessarily inconsistent with the observation that secured parties are concerned with security primarily to reduce the bankruptcy risk. After all, the primary reason for wanting priority in collateral vis-a-vis other secured parties is the same one that underlies the desire for such priority vis-a-vis unsecured creditors: The secured party must deal with the risk that the debtor will be unable to make all creditors whole.

Integration of the law of personal property security with that of bankruptcy, it should be noted, does not mean that the law of personal property security would be inapplicable outside of bankruptcy. The priority conflict between two secured parties that materialized without the formal initiation of bankruptcy proceedings, for example, would be governed by the same body of law. 150 While its federalization of and integration with bankruptcy law would" recognize the primacy of the bankruptcy risk, such integration need not diminish the law's relevance to other risks in other contexts.

\section{B. Conflicting Incentive Signals}

A second factor that argues for the integration of personal property security law with the law of bankruptcy is that, as currently drafted, article 9 and the Bankruptcy Code emit certain conflicting incentive signals. One can, of course, often criticize a body of law on the ground that its incentives to private actors may flout that same law's underlying legislative or doctrinal goals. For example, it has been contended that restriction on the rights of secured parties in bankruptcy may induce secured parties to take even greater security, thereby undermining the Bankruptcy Code's goal of expanding the estate of the debtor for the benefit of unsecured creditors. ${ }^{151}$ But the phenomenon of conflicting incentive signals occurs when the incentives created by one body of law are at cross purposes with the incentives created by another.

That article 9 and the Bankruptcy Code emit conflicting incentive signals should hardly surprise us. The overriding thrust of article 9 has been to protect security interests against various attacks that historically have been mounted against them. A major thrust of the Bankruptcy Code and its predecessors, on the other hand, has been to enhance the debtor's estate for the benefit of unsecured creditors by, among other things, empowering the trustee to vitiate some of the defenses of the secured party. Some tension is perhaps inevitable whenever the law implicates more than one interest, but what aggravates the tension here is the failure effectively to compromise and

150. Otherwise we would have created the side effect of differentiating between a secured creditor's rights in bankruptcy and those outside it. Without substantial cause for such differentiation, this consequence is highly undesirable. See infra note 181 .

151. See, e.g., White, The Recent Erosion of the Secured Creditor's Rights Through Cases, Rules and Statutory Changes in Bankruptcy Law, 53 Miss. L.J. 389, 426 (1983). 
to reconcile the respective competing interests in one statute. Hence, a clash occurs, resulting in conflicting, or at least inconsistent, incentive signals.

Consider, for example, the incentive operating on creditors to allow the debtor to retain use of his assets by permitting the creditor to file notice of his claimed security interest in that property. Although article 9 , as amended in 1972, seems to evince a general policy of indifference between filing a financing statement and taking possession of the collateral as alternative means of perfecting a security interest, arguably some preference for filing is exhibited. ${ }^{152}$ The rationale supporting this preference seems to lie in its facilitation of a functional division of the uses in property: The debtor gets the present productive use, while the secured party gets an interest to secure an obligation. True, the secured party's interest may be converted into a possessory use, but usually only upon the debtor's default.

Ostensibly, the Bankruptcy Code serves the same objectives: Section 362 automatically stays any attempt by secured creditors to seize their collateral, ${ }^{153}$ and section 542 empowers the trustee to collect all the debtor's property for the benefit of the bankrupt's estate. ${ }^{154}$ Moreover, the Supreme Court in United States $v$. Whiting Pools, Inc. ${ }^{155}$ has certainly strengthened the trustee's hand to force a turnover. But a careful reading of Justice Blackmun's opinion in Whiting Pools reveals that the holding was explicitly confined to property that had been seized by the creditor as a remedy-the Court did "not decide whether any property of the debtor in which a third party holds a possessory interest independent of a creditor's remedies is subject to turnover under sec. 542(a)."'156 Continuing, Justice Blackmun noted that "if property is pledged to the secured creditor so that the creditor has possession prior to any default, sec. 542(a) may not require turnover."'157 Indeed, I have been able to find no reported instance in which a secured party, having perfected its security interest by possession-for example, a brokerage firm with possession of the investment securities that secure the margin credit extended to the debtor-investor-was required to turn over the pledged collateral to the bankrupt estate. What is true for securities might well hold true for other types of assets.

In short, then, article 9 appears generally to favor the filed security interest over the possessory security interest-in that it supplies the secured party with an incentive to file and to leave the debtor in possession of his property. The Bankruptcy Code, as amended, however, may well be supplying the opposite incentive, because of the possibly untoward consequences to the secured party of allowing the debtor to remain in possession of his property.

152. See UCC $\$ 9-312(5)$ (a). The secured party who files first will win the priority conflict whether or not he first gives value to the debtor, but the secured party who first takes possession without giving value will lose out to the secured party who files first.

153. Bankruptcy Code $\S 362(a)(3) \&(4)$.

154. Id. § $542(\mathrm{a})$.

155. 462 U.S. 198 (1983).

156. Id. at 207-08 n.14.

157. Id. 
And where the debtor needs possession, there seems to be a tendency to structure the transaction so as to accord the debtor neither a legal nor arguably even an equitable title in the property. For example, some lawyers who advise equipment suppliers or financiers are counseling their clients to cast their dealings in the form of equipment leases rather than conditional sales. ${ }^{158}$

\section{Imperfect Docking}

Even when we cannot conclude that the incentives created by the Uniform Commercial Code and the Bankruptcy Code clearly conflict, another related phenomenon may be seen-a relational dynamic that I term "imperfect docking." Imperfect docking occurs when groups of statutory draftsmen, each aware of the work of the other and genuinely trying to coordinate their efforts, fail squarely to connect, and the misfit between the two statutes then exceeds the tolerance that is normally exhibited between two interrelated sections of the same legislation.

The drafters of article 9 and the Permanent Editorial Board of the Uniform Commercial Code that ratified the 1972 amendments were, of course, aware of the Bankruptcy Act. Similarly, the Commission on the Bankruptcy Laws of the United States, whose preliminary efforts foreshadowed much of the substance of the Bankruptcy Code, and those others who ultimately drafted the Code were aware of article 9 and its relevance to the law of bankruptcy. Moreover, although certain sections of article 9-sections 9-108 ${ }^{159}$ and 9$205^{160}$-may be read as a repudiation of then-existing bankruptcy law, article 9, by and large, echoed the Bankruptcy Act's policies and goals, including an abhorrence of both secret liens ${ }^{161}$ and of any realignment of the debtor's assets on the eve of bankruptcy in order to favor certain creditors. ${ }^{162}$ The Bankruptcy Code similarly was harmonized with the policies and goals of article 9 by protecting, among other things, floating liens, ${ }^{163}$ purchase money

158. See, e.g., Koch, Bankrupcy Planning for the Secured Lender, 99 Banking L.J. 788, $790-92$ (1982). Mr. Koch also advises that financiers take accounts and chattel paper in outright purchase transactions rather than as security for a loan to avoid its possible characterization as property of the debtor's estate under section 541 of the Bankruptcy Code. The importance of differentiating between security and purchase transactions in accounts and chattel paper for purposes of bankruptcy law, however, runs counter to one of the stated rationales for including both types of transactions within article 9. See UCC $\$ 9$-102.

159. The openly acknowledged purpose of section 9-108 was to save the floating lien from invalidation as a preferential transfer under section 60 of the Bankruptcy Act.

160. Section 9-205, which allows the debtor to commingle or dispose of collateral or proceeds without invalidating the security interest, was meant to overrule Benedict v. Ratner, 268 U.S. 353 (1925), which, although nominally an interpretation of state law, had a powerful impact on the rights of secured parties in bankruptcy proceedings.

161. The need to perfect the security interest, in most circumstances by filing a financing statement or taking possession of collateral so that others are put on notice of the secured party's interest, itself constitutes a strong statement against secret liens.

162. It is significant that UCC \& 9-108 only seeks to validate the floating lien where the debtor acquires the collateral "in the ordinary course of his business or under a contract of purchase made pursuant to the security agreement within a reasonable time after new value is given."

163. See Bankruptcy Code $\S 547(\mathrm{c})(5)$. 
security interests, ${ }^{164}$ and the perfected security interest against attack by the trustee as either a hypothetical ${ }^{165}$ or an actual creditor. ${ }^{166}$ Nonetheless, the extent of the accommodation between these bodies of law and the commonality of their generalized goals should not blind us to the degree to which imperfect docking occurred. Consider two examples: first, the protection afforded to purchase money security interests; and, second, the unending labyrinth of section $9-306(4)(d),{ }^{167}$ which seeks to define the extent of the secured party's interest in commingled bank accounts-that is, bank accounts in which both proceeds of the collateral and other monies have been deposited-upon the insolvency of the debtor.

Article 9 sharply differentiates between the purchase money secured party and the nonpurchase money secured party 168 and generally grants the former a period of ten days after delivery of the goods within which to file a financing statement. ${ }^{169}$ The rationale for this distinction is simply an unwillingness to impede the sale of goods on a purchase money credit basis by requiring the withholding of delivery pending filing in the absence of a serious risk that others will mistakenly and detrimentally rely upon the buyer's apparent ownership of the goods free of any security interest. The same consideration does not obtain in the nonpurchase money situation, so no delay in filing is sanctioned. Yet, section 547 of the Bankruptcy Code, for purposes of protecting a security interest against avoidance by the trustee as a preference, regards a transfer to have been made "at the time such transfer takes effect between the transferor [in article 9 terminology, the debtor] and the transferee [in article 9 terminology, the secured party], if such transfer is perfected at, or within 10 days after, such time."170 In other words, in the bankruptcy context, the ten-day grace period applies to the perfection of allnot simply purchase money-security interests. It is unclear why the Bankruptcy Code should protect a tardily perfected security interest in a

164. See id. $\S 547(\mathrm{c})(3)$.

165. See id. $\$ 544(\mathrm{a})(1)$.

166. Id. $\$ 544(\mathrm{~b})$.

167. UCC § 9-306(4)(d) reads:

In the event of insolvency proceedings instituted by or against a debtor, a secured party with a perfected security interest in proceeds has a perfected security interest only in the following proceeds: ... (d) in all cash and deposit accounts of the debtor in which proceeds have been commingled with other funds, but the perfected security interest under this paragraph (d) is ... (ii) limited to an amount not greater than the amount of any cash proceeds received by the debtor within ten days before the institution of the insolvency proceedings less the sum of (I) the payments to the secured party on account of cash proceeds received by the debtor during such period and (II) the cash proceeds received by the debtor during such period to which the secured party is entitled under paragraphs (a) through (c) of this subsection (4).

168. UCC $\$$ 9-107 defines purchase money security interests as those "(a) taken or retained by the seller of the collateral to secure all or part of its price; or (b) taken by a person who by making advances or incurring an obligation gives value to enable the debtor to acquire rights in or the use of collateral if such value is in fact so used."

169. See UCC $\$ \$ 9-301$ (2) (protection against lien creditors); 9-312(4) (protection against secured parties if collateral is other than inventory). But see \$ 9-812(3) (protection against prior secured parties if collateral is inventory only if filing is made before inventory is delivered to the debtor).

170. Bankruptcy Code $\$ 547(e)(2)$. 
situation where article 9 would not. Rather than the result of deliberate design, my suspicion is that this is an instance of imperfect docking. ${ }^{171}$

Another, more serious example of imperfect docking relates to the extent to which the secured party is recognized as having a perfected security interest in proceeds in the event of the debtor's insolvency. Here, article 9's drafters came to the problem later, and it is they who sought to effect a rendezvous with the federal law of bankruptcy. In the 1962 version of section 9-306(4) of the Uniform Commercial Code, the docking was barely visible. The drafters of the UCC were aware of the state-created priority and the statutory lien arguments that had been directed at the model for that provision, section 10 of the Uniform Trust Receipts Act. ${ }^{172}$ Nevertheless, they chose to run the preemption risk because they believed that a trade-off between the limitations on the rights of the secured party to reach proceeds and his recourse to the funds of the debtor without the necessity of tracing them was both feasible and fair. ${ }^{173}$ Their view of the debtor's assets as an aggregate mass was also reflected in their concept of the floating lien and the notice-filing system that did not require exact identification of collateral. ${ }^{174}$

In the 1972 version of the Uniform Commercial Code, the docking was more deliberate. The secured party became entitled only to funds in those commingled bank accounts in which proceeds had been deposited. ${ }^{175}$ And case law began to impose further limitations: Where proceeds were commingled with other deposited funds, the secured party would have a right only to those that he could have claimed apart from the bankruptcy proceeding. ${ }^{176}$ The net result has been highly paradoxical. By virtue of the present phraseology and interpretation of section 9-306(4), then, the secured party now receives less in the aggregate than he would have received outside

171. For a thorough treatment of the disparate treatment of delayed perfection under article 9 of the UCC and under the Bankruptcy Code, see Dawson, An Uneasy Relationship Between the Bankruptcy Reform Act and the Uniform Commercial Code: Delayed and Continued Perfection of Security Interests, 36 U. FLA. L. REV. 38 (1983).

172. See In re Harpeth Motors, Inc. 135 F. Supp. 863 (M.D. Tenn. 1955); In re Crosstown Motors, Inc., 272 F.2d 224 (7th Cir. 1959), cert. denied, 363 U.S. 811 (1960).

173. See 2 G. Gilmore, Security Interests in Personal Property \$ 45.9, at 1340 (1965). The 1962 version of UCC $\$ 9-306(4)$ (d) allowed the secured party to reach the debtor's bank accounts, regardless of whether proceeds had been deposited in the accounts, if proceeds had been deposited in any commingled account.

174. UCC $\$ 9-402(1)$ only requires that the financing statement indicate "the types ... of collateral." See Comment 2, UCC \$ 9-402.

175. See UCC $\$ 9-306(4)(d)$.

176. See, e.g., In re Gibson Products of Arizona, 543 F.2d 652 (9th Cir. 1976), cert. denied, 430 U.S. 946 (1977); In re Guaranteed Muffler Supply Company, Inc., 5 Bankr. 236 (Bankr. N.D. Ga. 1980). The court in the latter case stated:

[Section 9-306(2)] makes proceeds claims, by definition, depend upon a showing that the property claimed is identified as the fruit of a sale or other disposition of the original collateral. Thus, a right to proceeds of any kind, whether in bankruptcy or not, arises out of the language of section 9-306(2); the limitations upon "cash proceeds" listed in section 9-306(4)(d)(ii) therefore, include, by definition, the identifiability limitations which apply to all claims made to all proceeds. To require that proceeds claims be so limited is consistent with the fact that the exercise of lien rights is confined to specific property which the debtor has chosen to make available as a surrogate for his own performance.

Id. at 238-39. 
bankruptcy. ${ }^{177}$ And because the secured party receives nothing in bankruptcy to which he would not otherwise be entitled, no transactions costs are saved by using the subsection's formula rather than an explicit tracing approach to proceeds. ${ }^{178}$

In still another body of case law, courts have sought to coordinate section 9-306(4)(d) of the Uniform Commercial Code with section 547 of the Bankruptcy Code ${ }^{179}$-and again, the result can only be deemed imperfect. In these cases, prebankruptcy transfers of funds to the secured party have been invalidated as preferential without regard to whether the payment reduced the secured debt or the secured party was overcollateralized.180 Courts have reasoned that if, when bankruptcy ensues, section 9-306(4)(d) would not entitle the secured party to reach funds remaining in the debtor's commingled bank account, payment from such an account to the secured party is a preferential transfer under section 547 of the Code. As so used, in conjunction with section 547, section 9-306(4)(d) has become a weapon to attack the secured party with respect to payments made not simply within ten days of bankruptcy, but anytime within three months of bankruptcy.

No matter how erroneous, this judicial linkage of section 9-306(4)(d) of the Uniform Commercial Code and section 547 of the Bankruptcy Code may be justified by the need to obviate any distinction between the right of the secured party to take action inside and outside bankruptcy. Otherwise, parties would be encouraged to act in these matters on the basis of legal rather than business necessity. But while this judicial linkage may marginally reduce the incentive of the secured party to demand payment on the eve of bankruptcy, it creates inappropriate incentives to action by other parties. Clearly, a transformation of the debtor's assets from collateral such as inventory, chattel paper, or accounts into cash, particularly on the eve of bankruptcy, changes the relative entitlements between and among the secured and other parties. Consequently, other parties and sometimes the debtor, depending upon his

177. See, e.g., In re Cooper, 2 B.R. 188, 196 (S.D. Tex. 1980) (formula in § 9-306(4)(d) interpreted as "in lieu of the right to trace and [in limitation of] any right the secured creditor would have had in non-Code situations to trace proceeds by any means available").

178. As interpreted, UCC $\$ 9-306(4)(d)$ has not eased the problems of proof and of decisionmaking with respect to claims to proceeds by secured parties. See, e.g., In re Conklin, 14 B.R. 318 (D.S.C. 1981). There, after the debtor had filed a chapter 11 petition on December 14, 1979, the case was converted to a chapter 7 liquidation proceeding on April 1, 1980. Because the trustee had contested only the date from which the ten-day period should run under § 9-306(4)(d)-arguing that it should be April 1-the secured parties had addressed that point alone and had presented no proof as to commingled funds in the debtor's bank account prior to December 14. Although the court determined that December 14 was the crucial date for purposes of $\$ 9-306(4)$ (d), it nonetheless held that the secured parties were not entitled to the proceeds owing to the absence of such proof.

179. See, e.g., In re Jameson's Foods, 35 B.R. 433 (D.S.C. 1983) (funds remitted to secured party approximately two months before filing of petition); Fitzpatrick v. Philco Finance Corp., 491 F.2d 1288 (7th Cir. 1974) (payments made to secured party within ten days of bankruptcy).

180. But see In re Lackow Brothers, 19 B.R. 601 (Fla. 1981), where the court distinguished between situations in which a secured party is undersecured (the debt exceeds the value of collateral) and situations in which the secured party is fully secured or oversecured (the value of collateral exceeds the debt). In the latter instance, the court held that any payments made by the debtor to the secured party within 90 days of bankruptcy are not recoverable as a preferential transfer. 
relationship with the secured party, may be encouraged to initiate bankruptcy proceedings to enhance their relative shares. ${ }^{181}$

In short, there is simply no reason for the Uniform Commercial Code to limit the secured party's right to proceeds in the event of insolvency, as the law, both statutory and decisional, seems currently to dictate. There is no legitimate trade-off, and imperfect docking in this context has created incentives that are insupportable, whether one addresses the problem from the perspective of the secured party or that of the debtor and his estate.

\section{Direct Confrontation of Policy Issues}

The phenomena of conflicting incentive signals and imperfect docking evince a more fundamental reason for integrating bankruptcy and personal property security law: the difficulty of identifying and resolving policy issues when the policymaker confronts only part of the subject matter involved. And the literature and decisional law in this area suggest a whole range of policy issues that merit serious review. These include: What is the aggregate benefit to be derived from security interests-with the possible conclusion that such an institution is unjustifiable? Should any security interest, no matter how broadly articulated, be capable of covering more than a certain percentage of the debtor's property? Has the Bankruptcy Code conduced to bankruptcy where it could have been avoided by altering the rights of the parties outside bankruptcy? ${ }^{182}$ To what extent should the validity of floating liens be dependent upon either the nature of the collateral-whether inventory, accounts, chattel paper, or instruments-or a comparison of the value of the collateral on the date of bankruptcy and its value on an earlier date? ${ }^{183}$ Should enforcement of security interests be subject to stays in bankruptcy; and, if so, what constitutes adequate protection for the secured party? ${ }^{184}$

181. Professor Jackson has persuasively argued that bankruptcy law should "mirror the agreement one would expect the creditors to form among themselves were they able to negotiate such an agreement from an ex ante position." Jackson, Bankruptcy, Non-Bankruptcy Entitlements, and the Creditors' Bargain, 91 YALE L.J. 857, 860 (1982). Characterizing this as the "creditors' bargain," Professor Jackson views a reduction of strategic costs as an important if not essential aspect of maintaining the creditors' bargain. See id. at 861-64. See also Baird \& Jackson, Corporate Reorganizations and the Treatment of Diverse Ownership Interests: A Comment on Adequate Protection of Secured Creditors in Bankruptcy, 51 U. CHI. L. REv. 97, 101 (1984) (arguing that "protecting the value of a secured creditor's nonbankruptcy rights-whatever they might be-actually reinforces the bankruptcy policy of putting the firm's assets to their best use by placing the costs of trying to keep the assets of a firm together on those who stand to benefit from such an effort," and that if parties other than secured parties "do not bear these costs, they will have an incentive to place a firm in bankruptcy and to draw out the proceeding, even though doing so does not work to the advantage of those with rights to the firm's assets when their interests are considered as a group").

182. See Jackson, supra note 181; Baird \& Jackson, supra note 181.

183. The calculation required by section $547(\mathrm{c})(5)$ of the Bankruptcy Code (the trustee's power to avoid preferential transfers) as to the value of inventory and receivables 90 days before the bankruptcy petition is filed and the equivalent figure on the date of filing does not seem generally to have impacted the rights of secured parties adversely. See Ross, The Impact of Section 547 of the Bankrupicy Code upon Secured and Unsecured Creditors, 69 MinN. L. REv. 39 (1984).

184. See Nimmer, Secured Creditors and the Automatic Stay: Variable Bargain Models of Fairmess, 68 MinN. L. REv. 1 (1983) (arguing that the fifth amendment poses no obstacles to changing the creditors' bargain). 
Does equity require that secured parties receive a senior class of securities in bankruptcy reorganizations? ${ }^{185}$ Should secured parties enjoy lesser rights upon the debtor's bankruptcy than do other lien holders; and, if so, why? ${ }^{186}$ And should the scope of both after-acquired property and future advance clauses be curbed more than it has been under the 1962 and 1972 versions of article 9?

Such policy issues are not easy to resolve, and the answers of one generation may not seem appropriate to another. My point is simply that one is less likely to achieve adequate resolution-or even identification and discussion-of these issues if the policymaker's concern is definitionally confined to only part of the law integrally related to these issues.

\section{IV}

\section{CONCLUSION}

In this article, I have argued that the subject matter of article 9 of the Uniform Commercial Code, security interests in personal property, should be federalized and integrated with the Bankruptcy Code, although the substance of that law would obviously extend beyond the bankruptcy context. The arguments for federalization seem persuasive enough. These arguments include true uniformity of the law of secured transactions throughout the United States, the prospect of a more sensible national filing system, and the greater authority that a federalized law would carry. The dynamics between the Uniform Commercial Code and federal bankruptcy law, with at least two versions of article 9 and two different bankruptcy statutes under our belts of recent experience, including the conflicting signals and imperfect docking phenomena, reinforce the federalization idea.

Some would observe that my suggestion, while meritorious, is not as immediately urgent as are other legislative proposals related to bankruptcy. To this observation, I do not strongly object. On the other hand, however, deferring remedial legislation until the problem assumes crisis or near-crisis proportions carries the risk that much of the subject matter of article 9 may be federalized without the rationality entailed by the proposal that it be integrated with the Bankruptcy Code. Most tellingly, Congress recently included in the Food Security Act a provision that would protect the

185. See Roe, Bankruptcy and Debt: A New Model for Corporate Reorganization, 83 Colum. L. REv. 527 (1983). Professor Roe proposes that only common equity interests be issued in bankrupty reorganization when the debtor is recapitalized, arguing that neither equitable nor other factors require the issuance of senior securities, even to secured parties.

186. In In $r e$ Filterer Engineering Associates, 27 B.R. 878 (E.D.Mich. 1983), the question was whether a debtor in possession under chapter 11 could reject a contract that required a percentage of payments made under another contract to be remitted to Filterer Engineering Associates' attorneys. The attorneys had negotiated the contract in settlement of a patent dispute under which one-third of the payments in settlement would be made to the law firm. The court held the law firm to be entitled to the payments but said that if these had been accounts in which a secured party held a security interest, the attorneys would not have been so favored under section 547 (c). One of the distinctions the court drew was between security interests and other liens; in the court's judgment, the attorneys had a lien, even if that lien was reflected in a contract that assigned the sums involved. 
purchasers of farm products from security interests created by farmers, despite the explicit exclusion of persons "buying farm products from a person engaged in farming operations" from the classes of favored parties protected by section 9-307(1) of the Uniform Commercial Code. ${ }^{187}$ Although few would argue with the finding included in section 1324 of the Food Security Act that the present posture of the law "exposes purchasers of farm products to double payment" and, therefore, "constitutes a burden on and an obstruction to interstate commerce in farm products," 188 this mode of amending article 9 only exacerbates the problems of imperfect docking between federal and state law and the conflicting incentive signals the two bodies emit.

Indeed, perhaps all of commercial law currently covered by the Uniform Commercial Code merits federalization ${ }^{\mathbf{1 8 9}}$ - I do not exclude that possibility. If so, federalizing personal property security law could also be commended as an experimental first step in that direction.

187. Pub. L. No. 99-198, $§ 1324,99$ Stat. 1535 (1985). By excluding the purchasers of farm products from the protection offered by $\S 9-307(1)$, the UCC effectively protects the secured party at the expense of the buyer of farm products unless the disposition of the farm products free of the security interest "was authorized by the secured party in the security agreement or otherwise." UCC $\$ 9-306(2)$. Courts, however, have tended broadly to interpret the circumstances when authority has been given using the "or otherwise" phrase. See, e.g., Clovis National Bank v. Thomas, 77 N.M. 554, 425 P.2d 726 (1967) (court interpreting past practices as signifying such authority despite explicit provision in security agreement to the contrary). The Food Security Act strikes a different balance between secured creditors and buyers by imposing a filing requirement for both sets of parties. If they both comply, the buyer will have specific notice of the security interest but will, nonetheless, take free of it after having insured compliance with "any payment obligations imposed on the buyer by the secured party as conditions for waiver or release of the security interest." Pub. L. No. 99-198, $\$ 1324 \mathrm{~d}(\mathrm{~d})(5)$. If either the secured party or the purchaser fails to comply, so that notice of the security interest is not given, any loss owing to a failure of the buyer to comply with the terms of the security agreement will fall on the party who failed to file and thereby frustrated the specific notice scheme.

188. $§ 1324(\mathrm{a})(1)$.

189. Cf. Rice, Product Quality Laws and the Economics of Federalism, 65 B.U.L. REv. 1 (1985) (arguing that different product quality legislation has amounted to a subsidy flowing from those persons who reside in less protective states to those who reside in more protective states). While Professor Rice does not extend his analysis to a normative resolution, see id. at 60-64, he impliedly suggests that the part of article 2 of the UCC that deals with warranty questions might merit a federal rather than a state-by-state approach. 